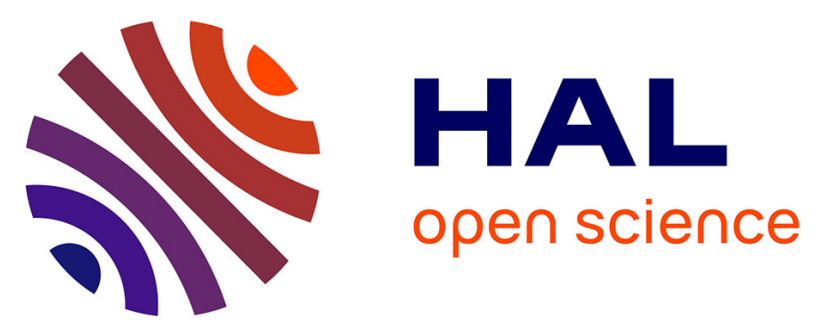

\title{
Synthesis and biological evaluation of diarylheptanoids as potential antioxidant and anti-inflammatory agents
}

Kelly Maurent, Corinne Vanucci-Bacqué, Michel Baltas, Anne Nègre-Salvayre, Nathalie Augé, Florence Bedos-Belval

\section{- To cite this version:}

Kelly Maurent, Corinne Vanucci-Bacqué, Michel Baltas, Anne Nègre-Salvayre, Nathalie Augé, et al.. Synthesis and biological evaluation of diarylheptanoids as potential antioxidant and antiinflammatory agents. European Journal of Medicinal Chemistry, 2018, 144 (7), pp.289-299. 10.1016/j.ejmech.2017.12.033 . hal-03118254

\section{HAL Id: hal-03118254 \\ https://hal.science/hal-03118254}

Submitted on 22 Jan 2021

HAL is a multi-disciplinary open access archive for the deposit and dissemination of scientific research documents, whether they are published or not. The documents may come from teaching and research institutions in France or abroad, or from public or private research centers.
L'archive ouverte pluridisciplinaire HAL, est destinée au dépôt et à la diffusion de documents scientifiques de niveau recherche, publiés ou non, émanant des établissements d'enseignement et de recherche français ou étrangers, des laboratoires publics ou privés. 


\title{
Synthesis and Biological Evaluation of Diarylheptanoids as Potential Antioxidant and Anti-inflammatory Agents
}

Kelly, Maurent, ${ }^{a, b}$ Corinne Vanucci-Bacquée ${ }^{a, b}$ Michel Baltas, ${ }^{a, b}$ Anne Nègre-Salvayre, ${ }^{c}$ Nathalie Augéc and Florence Bedos-Belval. ${ }^{a, b}$

a Université Paul Sabatier Toulouse III, UMR 5068, Laboratoire de Synthèse et Physico-Chimie de Molécules d'Intérêt Biologique, 118 Route de Narbonne, F-31062 Toulouse Cedex 9, France.

b CNRS, UMR 5068, Laboratoire de Synthèse et Physico-Chimie de Molécules d'Intérêt Biologique, 118 Route de Narbonne, F-31062 Toulouse Cedex 9, France. c INSERM, UMR1048, I2MC, BP 84225, 31432 Toulouse Cedex 4, France.

* Corresponding author: Tel.: +33 (0)5 615568 00; fax : +33 (0)561556011.

E-mail address: $\underline{\text { bedos@chimie.ups-tlse.fr }}$

\begin{abstract}
:
Reactive oxygen species (ROS) are key signaling molecules and their overproduction plays an important role in the inflammation process, the secretion of inflammatory cytokines such as IL-1 $\beta$ and IL- 6 and the progression of inflammatory disorders. Decreasing oxidative stress represents a promising challenge in the design of antioxidant and anti-inflammatory agents. In the present study, a series of new diarylheptanoids containing allylic alcohol, amide, hydantoin or triazole fragments were synthesized and fully characterized. We evaluated the ability of these agents to block the production of intracellular ROS and the subsequent inflammatory events exerted by lipopolysaccharide (LPS) on murine macrophage RAW 264.7. Five diarylheptanoids were found to exhibit the dual required properties.
\end{abstract}

Keywords : Diarylheptanoid, macrocycle, antioxidant, anti-inflammatory activity.

\section{Introduction}

Inflammation, one of the most important biological protective responses to tissue damage or microbial invasion, is able to induce cell injury, releasing pro-inflammatory 
mediators. Inflammation is associated with a large variety of human diseases such as rheumatoid arthritis, inflammatory bowel disease, neurodegenerative disorders, cancer and atherosclerosis [1]. Macrophages play a major role in the inflammatory response, by producing reactive oxygen species (ROS), reactive nitrogen species (RNS), and cytokines such as interleukin-1ß (IL-1ß), interleukin-6 (IL-6), tumor necrosis factor- $\alpha$ (TNF- $\alpha$ ), prostaglandin (PGE2) and the inflammatory mediator nitric oxide (NO) [2]. Nitric oxide is a major signaling agent with a short half-life and huge signaling properties [3]. NO is produced by several nitric oxide synthases (NOS), particularly e-NOS, which is constitutively expressed by endothelial cells, producing $\mathrm{NO}$ in the vascular wall [4]. At low concentrations, NO exerts various properties such as vasodilation, alongside anti-aggregant and protective properties in physiological and pathological processes. In contrast, large amounts of $\mathrm{NO}$ can be produced in response to inflammatory agents by the inducible NO synthase (iNOS) [5][6][7]. This $\mathrm{NO}$, combined with the superoxide anion $\mathrm{O}^{\circ-}$, forms peroxynitrite which is very harmful and toxic [7][8].

ROS are key-players of the proinflammatory signaling evoked by cytokines, LPS and stress-inducing agents involved in the progression of inflammatory diseases [9][10][11][12][13]. Inflammation and oxidative stress are inextricably linked, with complex feed-forward and feedback loops involved in the progression of chronic inflammatory diseases [14]. Consequently, new therapeutic strategies based on agents sharing both antioxidant and anti-inflammatory properties should be helpful to counter the development of chronic inflammatory diseases. A large number of drugs targeting the inflammatory responses are already available, including steroidal or nonsteroidal anti-inflammatory drugs. However many agents exhibit deleterious side effects, which reduces their interest as prolonged therapeutic applications, and raises the need of alternative non-toxic therapeutic strategies.

Polyphenols are naturally present in plants and exhibit many biological properties, among them the capacity to reduce inflammation [15]. Phenolic compounds and flavonoids [16] can interact with ROS/RNS and thus disrupt chain reaction before cell viability is really affected [17]. Among polyphenols, diarylheptanoids, a small class of plant secondary metabolites, consisting of two aromatic rings joined by a seven carbon chain and with various substituents, display strong antioxidant and anti-inflammatory properties [18][19]. This family of compounds can be further subdivided into linear 1,7- 
diarylheptanoids, such as the well-known curcumin (Fig. 1), and cyclic diarylheptanoids represented by meta,meta-bridged biphenyls and meta,para-bridged diphenyl ethers.

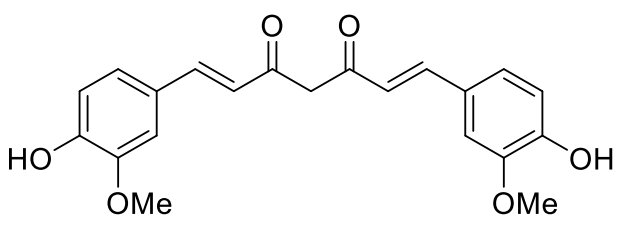

Curcumin

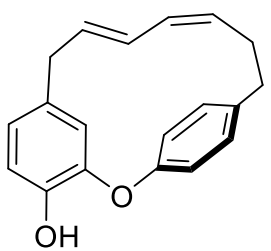

Tedarene A

Fig. 1. Structure of curcumin and tedarene $A$

Among them, we recently synthesized tedarene A (Fig. 1) [20], a phenolic diarylether macrocycle isolated from a marine sponge, which was reported to significantly inhibit NO production induced by LPS in $\mathbf{J 7 7 4}$ macrophages [21]. However, preliminary studies indicated that efficient tedarene A concentrations were partly toxic for macrophages RAW 264.7 cells (see below), perhaps due to the presence of a highly reactive dienic system on the heptanoid chain. This prompted us to design new series of diarylheptanoid analogues of tedarene $A$, by replacing the dienic chemical functionality embedded in the seven atom chain.

The heptanoid chain was modified to introduce various pharmacophore functions, to decrease the cytotoxicity and modulate the physicochemical and biological properties by comparison with tedarene $A$. This natural diarylether heptanoid features a unique aliphatic chain which makes it highly lipophilic $(C \log P=6.03)$ and non-druggable. In order to find therapeutic agents with improved drug-like properties, we introduced hydrogen bond donor and/or acceptor functions.

An allylic alcohol moiety was first inserted in the carbon chain (Fig.2, linker a) to increase the seven carbon chain flexibility compared to tedarene A. An amide function (Fig. 2, linker b), present in $25 \%$ of known drugs [22] was secondly integrated. Then, an exocyclic additional primary amine group was introduced at the $\alpha$-position to the amide function (Fig. 2, linker c). In order to modify the macrocycle strains, we envisioned to embed an extra cyclic moiety on the heptanoid chain. The imidazolidine2,4-dione pattern (Fig. 2, linker d), found in many biological active compounds, was identified as a valuable pharmacophore [23]. Finally, 1,2,3-triazole (Fig. 2, linker e) was 
selected as a linker displaying a bioisosteric effect, especially on peptide linkages and double bonds [24].

Herein we report the design and synthesis of phenolic or O-methylated diarylether heptanoid macrocycles $\mathbf{1}$ and $\mathbf{2}$, as analogues of tedarene $\mathrm{A}$, as well as their corresponding linear analogues 3, to probe the influence of the macrocyclic core on antioxidant and anti-inflammatory activities (Fig. 2). The antioxidant and antiinflammatory properties of these newly synthetized diarylheptanoids were investigated on their ability to block the generation of intracellular ROS, the production of nitrites, and the expression of IL-1 $\beta$ and IL-6 cytokine mRNAs, evoked by LPS in RAW 264.7 murine macrophages, in order to identify effective agents exhibiting dual biological capacities.

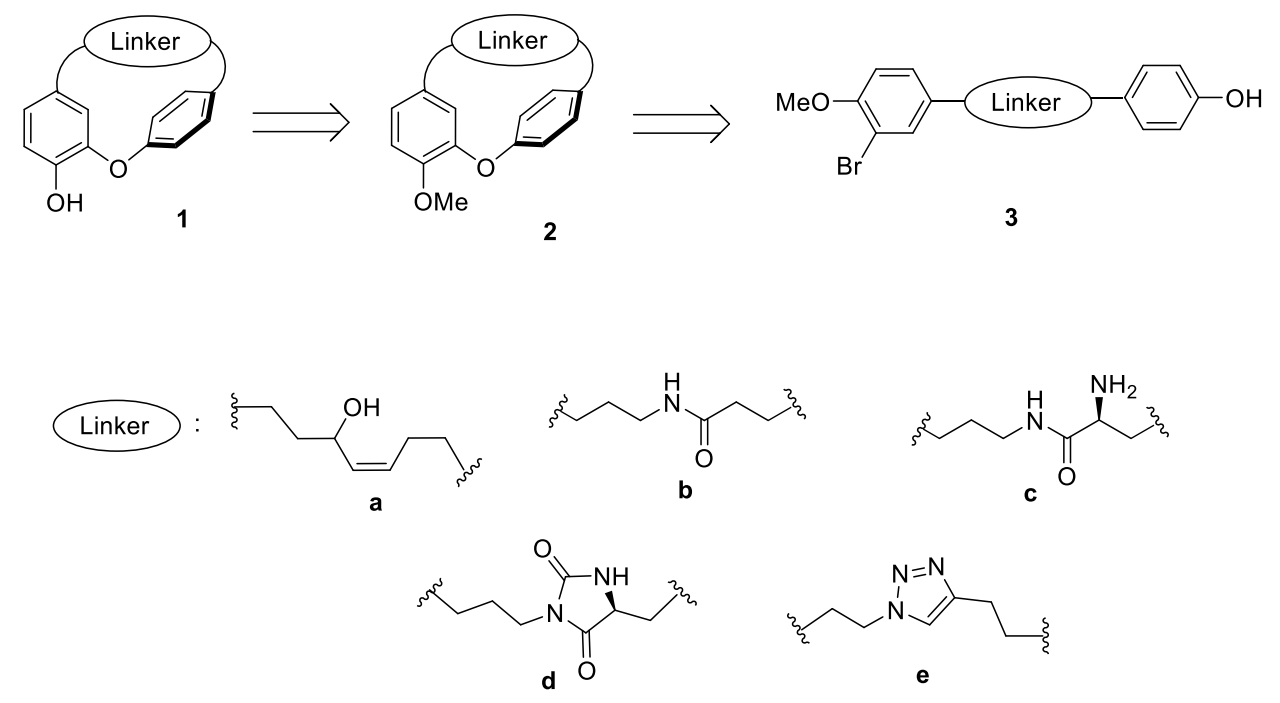

Fig. 2. Design strategy of a new series of tedarene $A$ analogues.

\section{Results and discussion}

\subsection{Chemistry}

The envisioned general retrosynthetic approach to obtain the macrocyclic structure involved an intramolecular Ullmann cyclisation of the corresponding linear bromo phenols. This approach allowed us to gain access to the macrocyclic phenolic and Omethylated derivatives $\mathbf{1}$ and $\mathbf{2}$, and to the linear phenols $\mathbf{3}$, in order to evaluate their biological activities (Fig. 2). 
Macrocyclic and linear diaryl heptanoids 1a, 2a and 3a, displaying an allylic alcohol function, were prepared as previously reported as they are intermediates encountered during the course of the total synthesis of tedarene A [20].

Heptanoid linkers displaying an amide moiety (linkers b, c and d, Fig.2) were obtained via a peptide-type coupling between a common phenylpropylamine 6 and an appropriate phenylpropanoic acid. Amine 6 was obtained by standard regioselective monobromination of the aromatic ring of amine 5 in $60 \%$ yield [18]. Condensations were performed with the commercially available 3-(4-hydroxyphenyl)propanoic acid 7, Boc-S-tyrosine 8, and the previously prepared tert-butyldimethylsilyl (TBS) protected Boc-S-Tyr(TBS)-OH [25] 9 in the presence of 1-ethyl-3-(3diméthylaminopropyl)carbodiimide (EDC), 1-hydroxybenzotriazole $(\mathrm{HOBt})$ and triethylamine. The corresponding linear diarylheptanoids $\mathbf{3 b}, \mathbf{1 0}$ and $\mathbf{1 1}$ were obtained in $75 \%, 83 \%$ and $51 \%$ respective yields (Scheme 1 ).

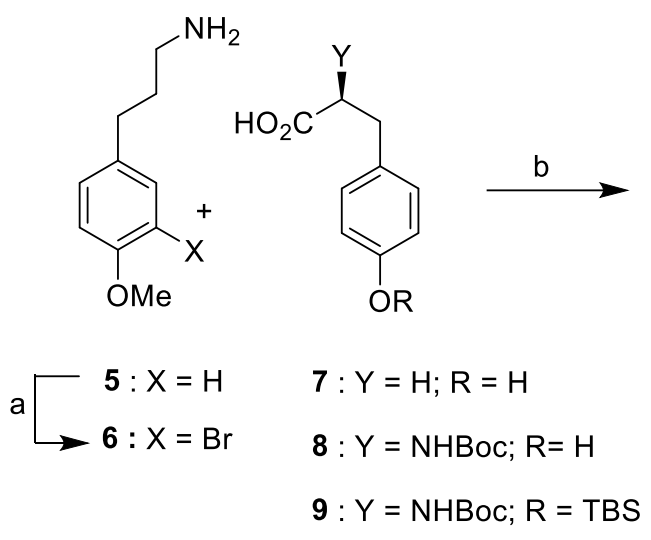

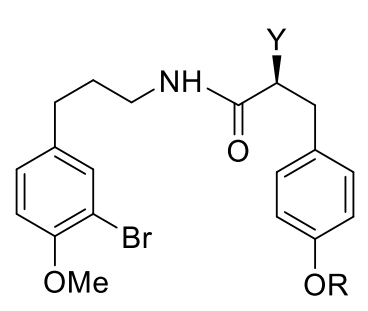

3b : $Y=H ; R=H$

$10: Y=N H B o c ; R=H$

$11: Y=$ NHBoc; $R=$ TBS

Scheme 1. Reagents and conditions: a) $\mathrm{Br}_{2}, \mathrm{AcOH}$, rt, $18 \mathrm{~h}$; b) EDC, $\mathrm{HOBt}, \mathrm{NEt}_{3}$, rt, 5 $\mathrm{h}$ in THF for $\mathbf{3 b}$ and $\mathbf{1 0}$ or $18 \mathrm{~h}$ in DMF for 11.

Macrocycles were obtained by intramolecular Ullmann cyclisation. This reaction performed in the presence of a copper species in basic medium requires long reaction times and high temperatures [26]. Heating can be achieved under conventional conditions or under microwave irradiation, which is known to allow shorter reaction 
times and higher yields [27]. As a result, the target macrocycles were obtained by microwave-assisted intramolecular Ullmann coupling.

Macrolactam $\mathbf{2 b}$ was directly obtained in $80 \%$ yield under standard conditions starting from bromophenol $\mathbf{3 b}$ in the presence of copper(II) oxide and potassium carbonate in pyridine at $150^{\circ} \mathrm{C}$ for $5 \mathrm{~h}$ under microwave irradiation (Scheme 2, A).

In order to avoid side reactions stemming from the reactivity of the tert-butoxycarbonyl group of diarylheptanoid 10, the carbamate function was removed by acidic treatment. The resulting amine 3c was rapidly converted to macrocycle $2 \mathrm{c}$ in $40 \%$ yield via Ullmann cyclisation under the same conditions as above $\left(\mathrm{MW}, 150^{\circ} \mathrm{C}, \mathrm{CuO} / \mathrm{K}_{2} \mathrm{CO}_{3}\right.$ in pyridine) (Scheme 2, B).

(A)

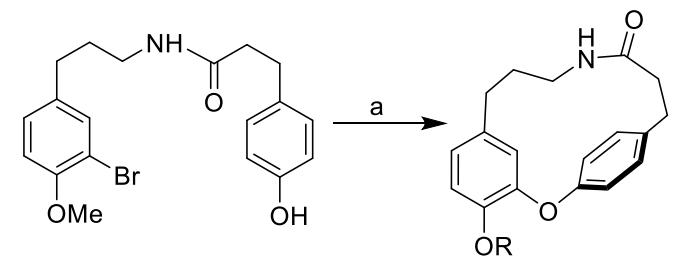

3b

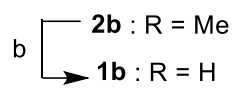

(B)

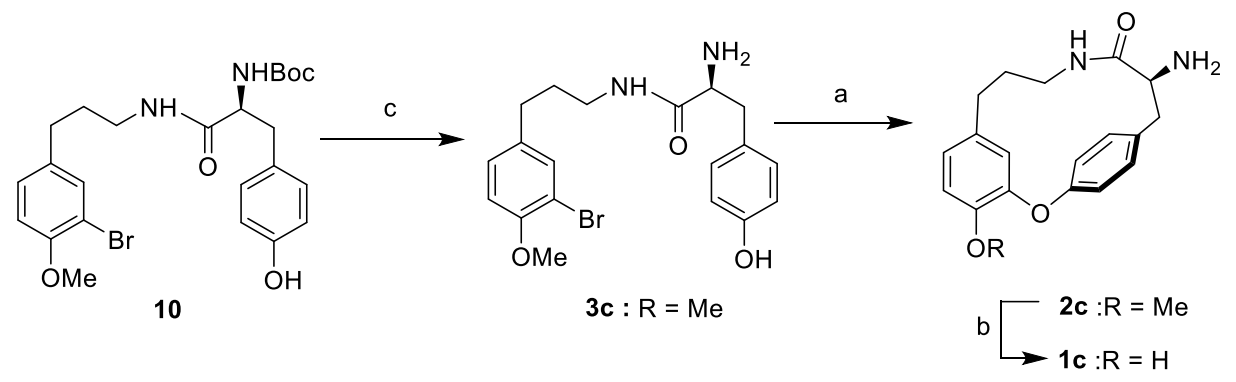

Scheme 2. Reagents and conditions: a) $\mathrm{CuO}, \mathrm{K}_{2} \mathrm{CO}_{3}$, pyridine, $\mathrm{MW}, 150^{\circ} \mathrm{C}, 5 \mathrm{~h}$; b) $\mathrm{BBr}_{3}, \mathrm{CH}_{2} \mathrm{Cl}_{2}, 2 \mathrm{~h}$; c) $\mathrm{HCl} /$ dioxane, $45^{\circ} \mathrm{C}, 30 \mathrm{~min}$.

The access to the 3,5-disubstituted hydantoin (imidazolidine-2,4-dione) moiety was efficiently accomplished in a single step cyclisation of the $\mathrm{N}$-Boc protected $\alpha$-amino amide $\mathbf{1 1}$ in the presence of trifluoromethanesulfonic anhydride and pyridine at room temperature [28]. This reaction was carried out starting from the tert-butyldimethylsilyl (TBS) protected phenol in order to avoid the formation of a triflate derivative, and gave the expected 1,7-diarylheptanoid $\mathbf{1 2}$ in $81 \%$ yield. After desilylation with tetra- $n$ butylammonium fluoride (TBAF), the linear bromophenol $\mathbf{3 d}$ was subjected to Ullmann 
cyclisation conditions under microwave heating. When accomplished in the presence of the $\mathrm{CuO} / \mathrm{K}_{2} \mathrm{CO}_{3}$ system, the reaction led to the target compound $2 \mathbf{d}$ in only $10 \%$ yield. The use of a copper (I) bromide dimethylsulfide complex and sodium hydride as base raised this yield to $53 \%$ (Scheme 3) [29].

Finally, cyclic diarylether heptanoids $\mathbf{2} \mathbf{b}-\mathbf{d}$ underwent O-demethylation by treatment with boron tribromide in dichloromethane to provide the corresponding phenols $\mathbf{1} \mathbf{b}-\mathbf{d}$ (47-80\% yields) (Schemes 2 and 3 ).
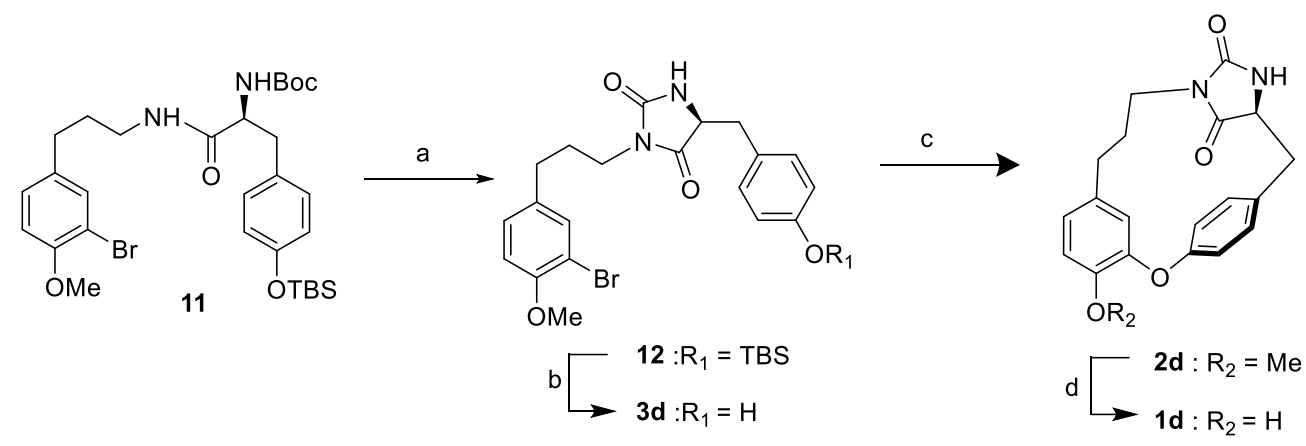

Scheme 3. Reagents and conditions: a) $\mathrm{Tf}_{2} \mathrm{O}$, pyridine, $\mathrm{CH}_{2} \mathrm{Cl}_{2}$, rt, 1h; b) TBAF, THF, $0^{\circ} \mathrm{C}, 10 \mathrm{~min}$; c) CuBr-DMS, NaH, pyridine, $\mathrm{MW}, 150^{\circ} \mathrm{C}, 30 \mathrm{~min}$; d) $\mathrm{BBr}_{3}, \mathrm{CH}_{2} \mathrm{Cl}_{2},-78^{\circ} \mathrm{C}$ to $0^{\circ} \mathrm{C}, 1 \mathrm{~h}$.

Concerning the 1,2,3-triazole embedded linker, diarylheptanoid $\mathbf{1 5}$ was obtained by a Huisgen's cycloaddition between azide 13 and alkyne 14 (Scheme 4). Bromo azide 13 was prepared in three steps from commercially available 2-(4-methoxyphenyl)ethan1-ol, after monobromination of the aromatic ring, mesylation and substitution [30]. Alkyne 14 was obtained from 4-hydroxybenzaldehyde via a known three-step sequence [31]. The click reaction performed in the presence of sodium ascorbate and copper sulphate gave rise to the 1,2,3-triazole derivative 15 in $83 \%$ yield. Cleavage of the tert-butyldimethylsilyl group of $\mathbf{1 5}$ was readily accomplished in $83 \%$ yield by treatment with TBAF in THF. Subsequent Ullmann cyclisation of bromophenol $3 \mathbf{e}$ was achieved as previously described $\left(\mathrm{CuO} / \mathrm{K}_{2} \mathrm{CO}_{3}\right)$, under microwave irradiation at $150^{\circ} \mathrm{C}$ for 5 h, to provide macrocycle $2 \mathbf{e}$ in $71 \%$ yield. In turn, O-demethylation of derivative $\mathbf{2 e}$ was carried out upon treatment with boron tribromide in $\mathrm{CH}_{2} \mathrm{Cl}_{2}$ to give the corresponding phenol $1 \mathrm{e}$ in $80 \%$ isolated yields. 


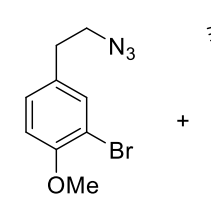

13

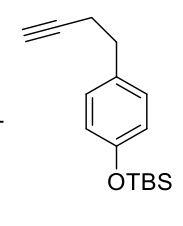

14

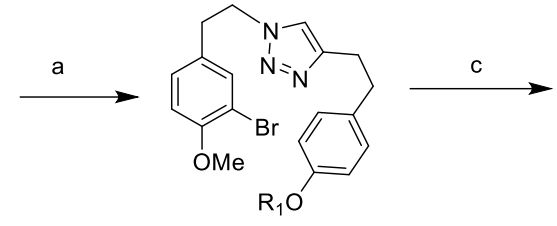

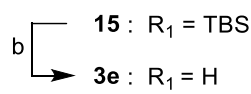
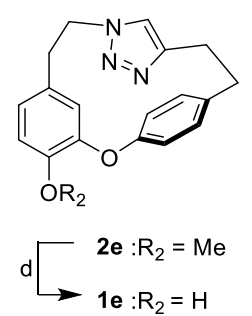

Scheme 4. Reagents and conditions: a) Sodium ascorbate, $\mathrm{CuSO}_{4}-5 \mathrm{H}_{2} \mathrm{O}, \mathrm{THF} / \mathrm{H}_{2} \mathrm{O}$, rt, 18h; b) TBAF, THF, $0^{\circ} \mathrm{C}$, 3h; c) $\mathrm{CuO}, \mathrm{K}_{2} \mathrm{CO}_{3}$, pyridine, $\mathrm{MW}, 150^{\circ} \mathrm{C}, 5 \mathrm{~h}$; d) $\mathrm{BBr}_{3}$, $\mathrm{CH}_{2} \mathrm{Cl}_{2},-78^{\circ} \mathrm{C}, 1 \mathrm{~h}$.

\subsection{Biological evaluation}

\subsubsection{Cell viability assay}

The biological properties of the synthesized agents were investigated on murine RAW 264.7 macrophages which are suitable cellular models for evaluating inflammation and the protective effect of drugs [32]. We first evaluated the "self" toxicity of each compound using Trolox as referent antioxidant. The cell viability was evaluated on RAW 264.7 macrophages exposed to the different agents, using the MTT test, as previously reported [33]. For this screening, we have chosen to test the agents at a 30 $\mu \mathrm{M}$ concentration, as the previous report by Costantino and coworkers [21] had shown that tedarene $\mathrm{A}$ is efficient at $30 \mu \mathrm{M}$ against $\mathrm{NO}$ production, whereas lower concentrations are not active.

We found that tedarene $\mathrm{A}$ is toxic at $30 \mu \mathrm{M}$ for RAW 264.7 macrophages, with a residual cell viability of less than $60 \%$, after $18 \mathrm{~h}$ incubation (Fig.3) and a clear dosedependent toxicity when compared to the untreated control (Supporting information, Supplemental Fig.I). Likewise, compound 3a was toxic at $30 \mu \mathrm{M}$, for macrophages, when compared to the untreated control. Note that no toxicity was observed in the first hours of incubation with these agents. All the other compounds were not toxic (cell viability comparable to that of the untreated control) at $30 \mu \mathrm{M}$ (Fig.3). 


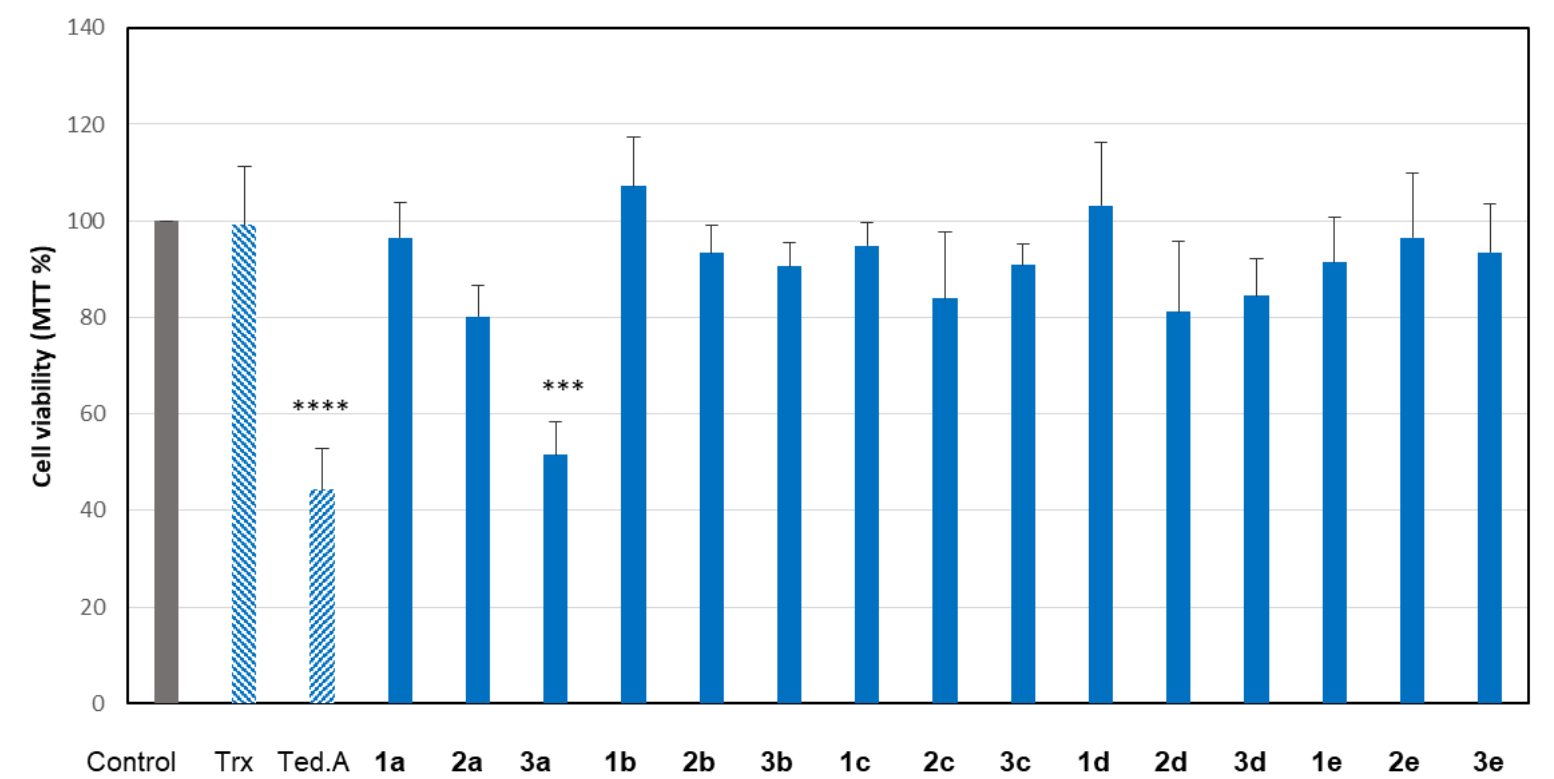

Fig. 3. Self-toxicity of diarylheptanoid agents. RAW 264.7 macrophages were incubated with Trolox ( $\operatorname{Trx}$ ), tedarene A (Ted. A) or the other newly synthesized agents (final concentration $30 \mu \mathrm{M}$ for all the tested agents). The cell viability was evaluated by the MTT assay after $18 \mathrm{~h}$ incubation at $37^{\circ} \mathrm{C}$. The results are expressed as $\%$ of the unstimulated control (grey bar). Mean \pm SEM of 5 separate experiments. *: Untreated control used as reference, ${ }^{* * *} p<0.001,{ }^{* * * *} p<0.0001$.

\subsubsection{Inhibition of intracellular ROS generated by LPS.}

We then checked the ability of the newly synthetized compounds to inhibit the intracellular ROS increase evoked by LPS in RAW 264.7. Indeed, previous reports have shown that LPS rapidly stimulates the production of intracellular ROS, and this can be inhibited by antioxidants such as curcumin [10][11][12]. For this purpose, we used the ROS-sensitive probe $\mathrm{H}_{2}$ DCFDA-AM (Fig. 4). As expected, LPS stimulated intracellular ROS production, which was significantly increased after $4 \mathrm{~h}$ incubation with RAW 264.7 (by comparison with the untreated control). Trolox, used as reference antioxidant, dose-dependently inhibited the intracellular ROS production evoked by LPS (30 $\mu \mathrm{M}<\mathrm{IC}_{50}<50 \mu \mathrm{M}$, Supporting information, Supplemental Fig. II). Tedarene A significantly inhibited ROS production at $30 \mu \mathrm{M}$ (Fig.4), but had no effect at lower concentrations (Supporting information, Supplemental Fig. II). 
The effect of the new agents on ROS production was compared to that evoked by LPS alone $\left({ }^{*}\right)$ and to that of tedarene A used as reference compound (\#). Among the 15 tested agents, 6 were found to be significantly efficient. More precisely, the phenolic allylic alcohol $\mathbf{1 a}$ and at a lesser extent, the diarylheptanoid 3a, significantly inhibited ROS production at $30 \mu \mathrm{M}$. The phenolic amide-type agents $\mathbf{1 b}$ and $\mathbf{3 b}$, were significantly protective, but their effect was weaker than that elicited by other agents.

The tyrosine derived compounds $\mathbf{1 - 3 c}$, which possess an additional primary amine function on the seven atom chain, exhibited a different ROS inhibition activity to that of the amide analogues 1-3b. A loss of antioxidant activity of phenolic macrocycle 1c, compared to amide $\mathbf{1 b}$, was observed. The phenolic linear agent $\mathbf{3 c}$, was comparable to that of tedarene $A$, and was better than that of its amide counterpart $\mathbf{3 b}$. The phenolic linear agent $\mathbf{3 c}$, exhibited a strong inhibitory effect, higher than tedarene $A$ and trolox, and better than that of its amide counterpart $\mathbf{3 b}$. Finally, the non-phenolic macrocycle 2c significantly inhibited ROS production, with an efficacy comparable to tedarene A. In this case, the lack of a phenolic function was compensated by the presence of the primary amine.

The imidazolidine-2,4-dione and 1,2,3-triazole derivatives, containing a five-membered ring in the heptanoid chain, exhibited no antioxidant ability even with the presence of phenol groups which is therefore not sufficient to induce this activity. Consequently, an additional cyclic moiety on the heptanoid chain does not appear to be relevant in the inhibition of intracellular ROS production.

These results point out the inhibitory effect of the agents on intracellular ROS production stimulated by LPS, and their correlation with the cell viability data, particularly those concerning the toxicity of agent $3 a$. This data allowed us to select five diaryl heptanoids: three macrocyles $\mathbf{1 a}, \mathbf{1} \mathbf{b}$ and $\mathbf{2 c}$, and two linear bromo phenols $\mathbf{3 b}$ and $\mathbf{3 c}$, which were evaluated on inflammation parameters. As for tedarene $A$, we aimed at verifying the dose-dependent toxicity of the selected agents (Supporting information, Supplemental Fig. I), and their dose-dependent inhibitory effect on ROS production evoked by LPS (Supporting information, Supplemental Fig. II). These agents are not toxic for macrophages up to $30 \mu \mathrm{M}$, with slight toxicity between 30 and $50 \mu \mathrm{M}$ (agents 1a and $\mathbf{3 b}$ ), and no significant toxicity for the other compounds. Likewise, dose-response experiments show that all the tested agents significantly block ROS production evoked by LPS, with strong efficacy for the compounds 1a and 
3c. The $\mathrm{IC}_{50}$ of the different compounds on ROS inhibition was around $30 \mu \mathrm{M}$ for tedarene A, Trolox, compounds $\mathbf{2 c}$ and $\mathbf{3 c}$, and between 30 and $50 \mu \mathrm{M}$ for the compounds $\mathbf{1 a}, \mathbf{1} \mathbf{b}$ and $\mathbf{3 b}$. Further experiments on cytokines were carried out on short periods of time (up to $4 \mathrm{~h}$ ), using a $30 \mu \mathrm{M}$ concentration for all compounds.

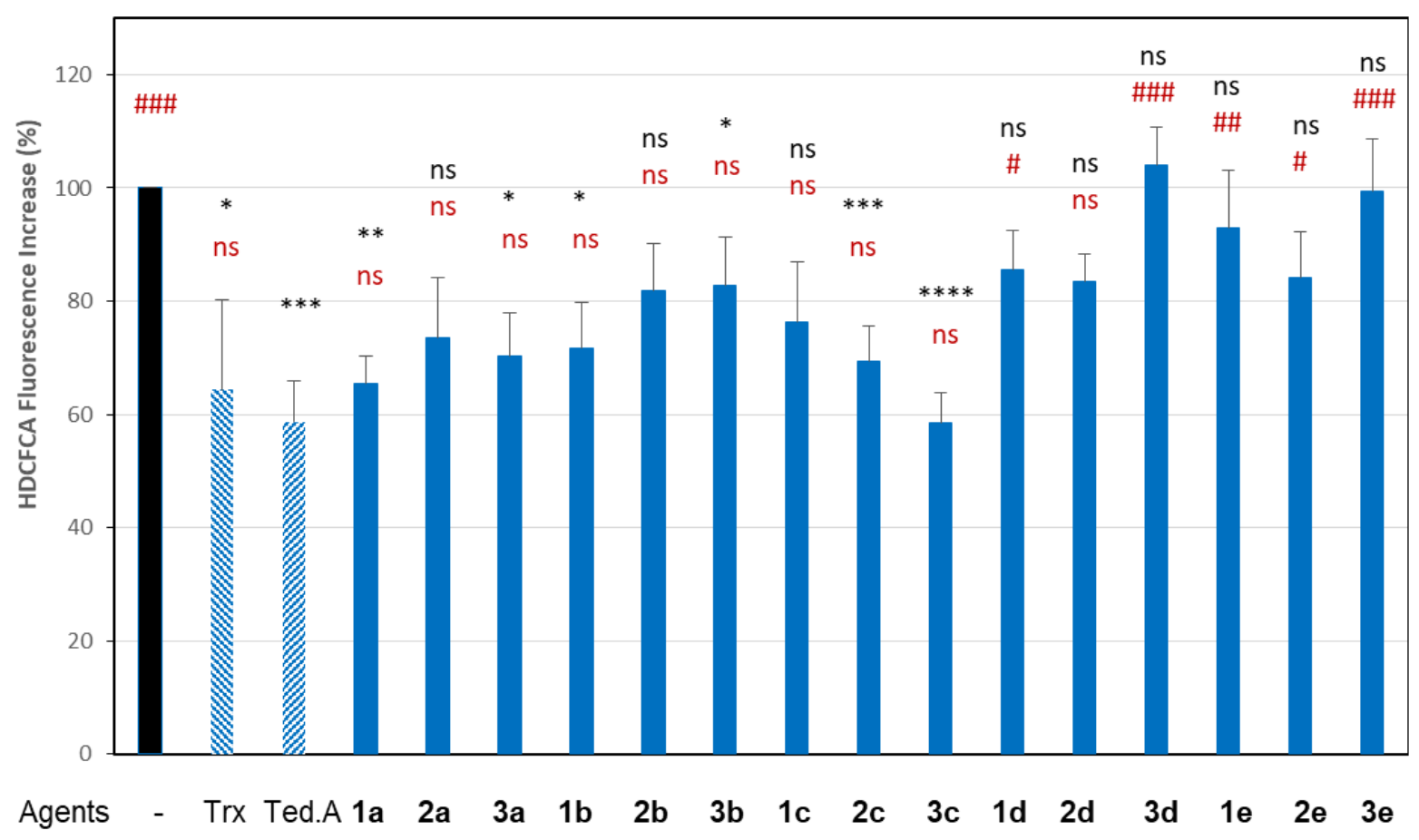

Fig.4. Effect of the diarylheptanoid agents on the intracellular ROS increase evoked by LPS. Intracellular ROS production was measured in RAW 264.7 stimulated for $4 \mathrm{~h}$ with LPS $(20 \mathrm{ng} / \mathrm{mL})$ without (100\%, black bar), or with Trolox (Trx), tedarene A (Ted. A) or the different agents $(30 \mu \mathrm{M})$, in serum-free culture medium. 30 minutes before the end of the experiment, the culture medium was removed and replaced by a medium containing the fluorescent ROS-sensitive $\mathrm{H}_{2}$ DCFDA-AM probe $(5 \mu \mathrm{M})$. After carefully washing the cells in PBS, RAW 264.7 were homogenized in water, and the fluorescence was read as indicated in the Experimental Section. Results were normalized using the fluorescence of LPS-stimulated cells. Mean \pm SEM of 6 separate experiments. ": LPS used as reference (annotated in black), ${ }^{*} p<0.05 ;{ }^{* *} p<0.01$, ${ }^{* \star *} p<0.001,{ }^{* * *} p<0.0001$ (annotated in black). ${ }^{*}$ Ted. A used as reference (annotated in red), ${ }^{p}<<0.05 ;{ }^{\#} \mathrm{p}<0.01,{ }^{\# \#} \mathrm{p}<0.001$ (annotated in red). ns : non-significant. 


\subsubsection{Anti-inflammatory activity}

\subsubsection{Effect of the agents on the nitrite production elicited by LPS}

Peroxynitrites and nitrites represent the final products of the NO oxidation pathway. Thus, determining the level of nitrite $\mathrm{NO}_{2}{ }^{-}$formation in cell culture medium is indicative of NO production via inflammation. The effect of the newly synthesized compounds $\mathbf{1 a}$, 1b, 3b, 2c and $\mathbf{3 c}$ was checked against nitrite production by LPS stimulated RAW 264.7. Nitrite levels were evaluated on the culture medium after $4 \mathrm{~h}$ of contact with LPS, in the presence (or absence) of the different agents, using the Griess reaction technique. Tedarene A was used as reference (Fig. 5). Under these conditions, tedarene A was able to inhibit more than $65 \%$ of LPS-induced NO production, in agreement with previous reports in J774 cells [21].

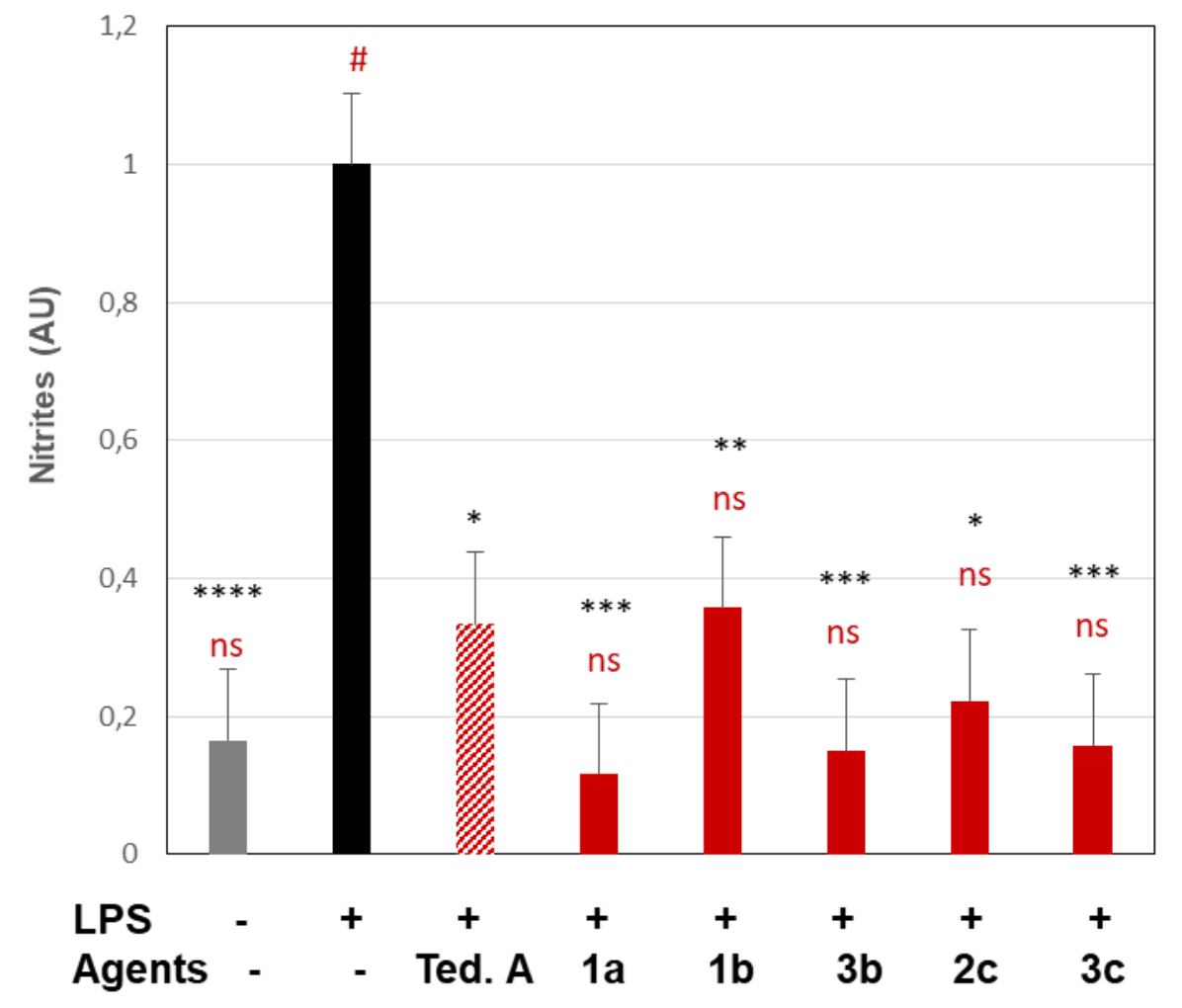

Fig.5. Effect of the diarylheptanoid agents on LPS-mediated nitrite production. RAW 264.7 cells were pretreated tedarene A (Ted. A) and the agents $(30 \mu \mathrm{M})$ for 30 min and then treated with LPS $(20 \mathrm{ng} / \mathrm{mL})$ for $4 \mathrm{~h}$. Results are expressed as percentage nitrite production elicited by LPS. Mean \pm SEM of 5 separate experiments. ${ }^{*}$ : LPS used 
as reference (annotated in black) , ${ }^{*} \mathrm{p}<0.05 ;{ }^{* *} \mathrm{p}<0.01,{ }^{* \star *} \mathrm{p}<0.001,{ }^{* \star *} \mathrm{p}<0.0001 .{ }^{\#}$ : Ted. A used as reference, ${ }^{\#} p<0.05$ (annotated in red). ns : non-significant.

All compounds significantly decreased the nitrite levels evoked by LPS (Fig. 5). Macrocyclic diarylether $\mathbf{1 b}$ inhibited nitrite production (around 65\%) in the same range as tedarene $A$. The other derivatives $\mathbf{1 a}, \mathbf{3 b}, \mathbf{2} \mathbf{c}$ and $\mathbf{3} \mathbf{c}$ were more efficient than tedarene $\mathrm{A}$, showing more than $80 \%$ inhibition, with the most potent being the phenolic macrocycle 1a.

\subsubsection{Effect of the compounds on the expression of pro-inflammatory cytokines evoked by LPS}

The inflammatory signaling of LPS and other stress-inducing agents results in the production of a variety of cytokines, chemokines, adhesion molecules, and inflammation mediators [32]. We aimed at investigating whether the new diarylheptanoid agents may block the expression of cytokine IL-1 $\beta$ and IL-6 mRNAs evoked by LPS. As shown in Fig. 6 , all compounds significantly blocked the expression of IL-1 $\beta$ and IL- 6 mRNAs evoked by LPS, after 4h incubation with macrophages. Furthermore, almost all the agents were as efficient as tedarene A with 30 to $50 \%$ of inhibition on IL-1 $\beta$ mRNAs expression and more than $60 \%$ of inhibition on IL- 6 mRNA expression.

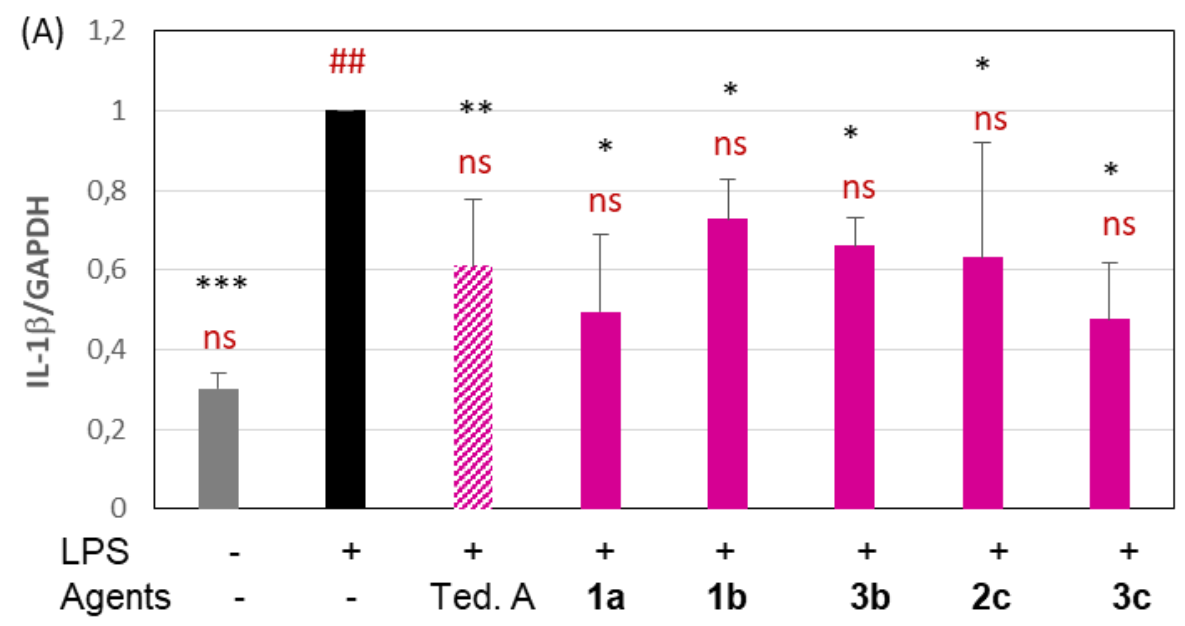




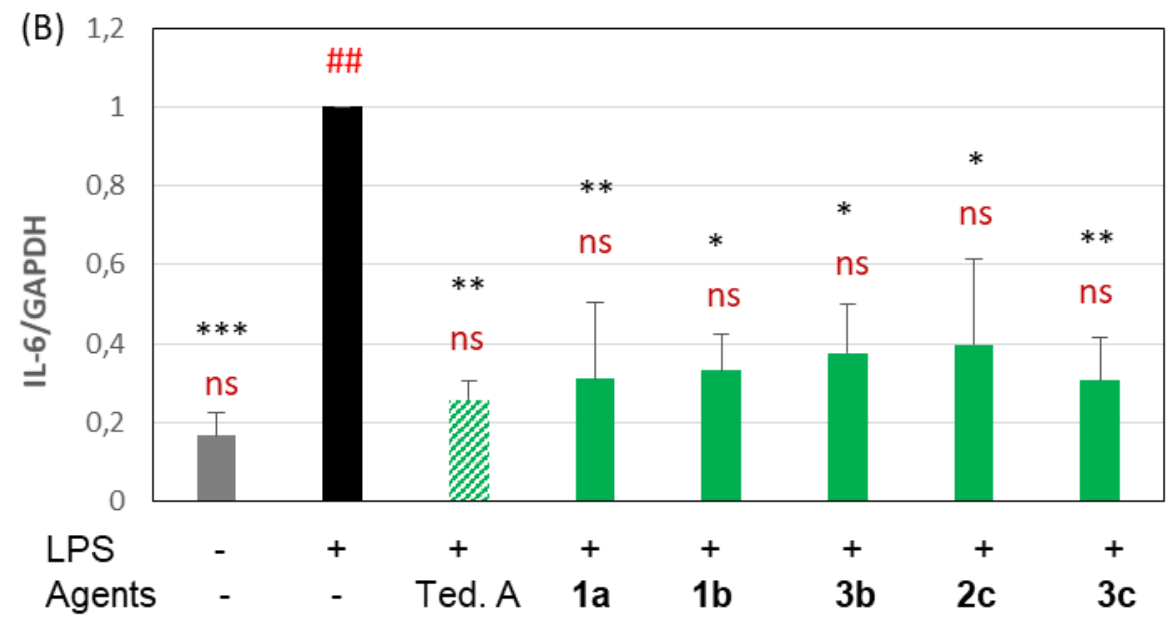

Fig.6. Effect of the diarylheptanoid agents on the expression of IL-1 $\beta$ and IL-6 mRNA expression evoked by LPS. RAW 264.7 cells were pretreated with tedarene A (Ted. A) or the agents $(30 \mu \mathrm{M})$ for $30 \mathrm{~min}$ and then stimulated by LPS $(20 \mathrm{ng} / \mathrm{mL})$ for 4h. In A, expression of IL-1 $\beta$ mRNAs, in B, IL-6. The results are normalized to the reference gene GAPDH, and expressed as ratio/ LPS-stimulated cells. Mean \pm SEM of 5 separate experiments. *: LPS used as reference (annotated in black), ${ }^{*} p<0.05$; ${ }^{* *} p<0.01,{ }^{* * *} p<0.001$. ${ }^{\#}$ : Ted. A used as reference (annotated in red), ${ }^{\# \#} p<0.01$. ns : non-significant.

\section{Conclusion}

The aim of this work was to synthesize a series of linear and macrocyclic analogues and test their potential antioxidant and anti-inflammatory efficacy against LPS-induced cellular responses in macrophages. The lead compound tedarene A inhibits LPSinduced ROS and NO production, therefore it presents anti-inflammatory properties. However, the toxicity of this agent limits its use in biological systems and living organisms. Among the 15 newly synthesized diarylheptanoid agents, five compounds were found to have similar or higher efficacy than tedarene A to block ROS production evoked by LPS, but were devoid of its toxic side effects. Moreover, these agents were as efficient as tedarene A to block the production of nitrites induced by LPS in RAW 264.7 macrophages. Since nitrite generation reflects the production of NO but also its combination to superoxide anion which forms $\mathrm{NO}_{2}^{-}$, it is likely that these agents inhibit nitrite formation by blocking the production of $\mathrm{O}_{2}{ }^{\circ}$, as suggested by the inhibition of 
ROS production. In addition, all these agents inhibited more efficiently than tedarene A the expression of cytokines mRNAs such as IL-1 $\beta$ and IL- 6 . It can be expected that these diarylheptanoid agents should inhibit the inflammatory signaling pathways evoked by LPS, such as the activation of inflammasomes NLRP, or the NFKB pathway, due to their inhibition by curcumin [34][35]. The important point is that all the five tested linear or macrocyclic agents exhibit antioxidant and anti-inflammatory properties comparable to tedarene $\mathrm{A}$, but are however much less toxic (at the tested concentration), which emphasizes their potential interest for therapeutic purposes. These activities do not appear clearly correlated to the chemical structure (macrocyclic versus linear) of the agents. Based on these results, further studies aimed at synthesizing more potent anti-inflammatory agents are currently in progress.

\section{Experimental section}

\subsection{Chemistry}

\subsubsection{General}

Unless otherwise noted, all experiments were carried out under a nitrogen atmosphere. Solvents $\left(\mathrm{CH}_{2} \mathrm{Cl}_{2}\right.$ and THF) were dried via a purification solvent system MB-SP- 800 (MBRAUN). Melting points (Mp) were obtained on a Buchi apparatus and are uncorrected. Measurements above $200^{\circ} \mathrm{C}$ were not possible with this apparatus. IR spectra were recorded on a Thermo Nicolet Nexus spectrometer. NMR spectra were recorded on Brucker Avance $300 \mathrm{MHz}$ spectrometer. The NMR spectra were acquired in $\mathrm{CDCl}_{3}, \mathrm{CD}_{3} \mathrm{OD}$ or DMSO- $d_{6}$, and the chemical shifts were reported in parts per million (ppm) with the solvent residual peaks as references. Signals are described as follow: s, singlet; brs, broad signal; $d$, doublet; $t$, triplet; $m$, multiplet. HRMS data were recorded on a Xevo G2 QTOF (Waters) instrument. Reactions were monitored by TLC on silica gel Alugram ${ }^{\circledR}$ Xtra SIL $G / \cup_{254}$. Column chromatography was performed on Machery-Nagel silica gel 0.063-0.2 mm. Reactions utilizing microwave technology were conducted in a CEM Discover Benchmate microwave reactor (model no. 908010).

4.1.2. 3-(3-bromo-4-methoxyphenyl)propan-1-amine (6).To a solution of amine 5 (1.72 $\mathrm{g}, 10.4 \mathrm{mmol})$ in glacial $\mathrm{AcOH}(19 \mathrm{~mL})$ was added dropwise a solution of $\mathrm{Br}_{2}(0.64 \mathrm{~mL}$, 
$12.5 \mathrm{mmol}$ ) in $\mathrm{AcOH}(15 \mathrm{~mL})$. The reaction mixture was stirred at rt overnight and quenched with water. The aqueous layer was extracted with $\mathrm{CH}_{2} \mathrm{Cl}_{2}$ and the combined organic layers were washed with water. The combined aqueous layer was basified to $\mathrm{pH}=9$ by addition of solid $\mathrm{Na}_{2} \mathrm{CO}_{3}$, then extracted with $\mathrm{CH}_{2} \mathrm{Cl}_{2}$. The obtained combined organic layer was washed with water, brine, dried over $\mathrm{Na}_{2} \mathrm{SO}_{4}$ and concentrated under reduced pressure to give the expected compound $6(1.53 \mathrm{~g}, 60 \%)$ as a yellow oil, pure enough to be used without further purification. IR $(\mathrm{KBr}) v_{\max }: 3364,1498 \mathrm{~cm}^{-}$ 1. ${ }^{1} \mathrm{H} \mathrm{NMR}(300 \mathrm{MHz}, \mathrm{MeOD}) \delta: 7.37(\mathrm{~d}, J=2.1 \mathrm{~Hz}, 1 \mathrm{H}) ; 7.13(\mathrm{dd}, J=2.1,8.4 \mathrm{~Hz}, 1 \mathrm{H})$; $6.92(\mathrm{~d}, J=8.4 \mathrm{~Hz}, 1 \mathrm{H}) ; 3.82(\mathrm{~s}, 3 \mathrm{H}) ; 2.64-2.53(\mathrm{~m}, 4 \mathrm{H}) ; 1.72(\mathrm{q}, J=7.5 \mathrm{~Hz}, 2 \mathrm{H}) .{ }^{13} \mathrm{C}$

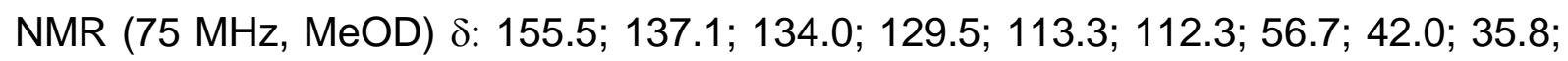
32.9. HRMS ( $\left.\mathrm{DCl}, \mathrm{CH}_{4}\right) \mathrm{m} / \mathrm{z}$ calcd for $\mathrm{C}_{10} \mathrm{H}_{14} \mathrm{NOBr}[\mathrm{M}+\mathrm{H}]^{+}: 244.0337$, found: 244.0347 .

\subsubsection{N-(3-(3-bromo-4-methoxyphenyl)propyl)-3-(4-hydroxyphenyl)propanamide} (3b).To a solution of amine $6(317 \mathrm{mg}, 1.3 \mathrm{mmol})$ in anhydrous THF ( $3 \mathrm{~mL})$ at room temperature were added successively the acid 7 (200 mg, $1.2 \mathrm{mmol}$ ), HOBt (16 mg, $0.12 \mathrm{mmol})$, EDC (202 $\mathrm{mg}, 1.3 \mathrm{mmol})$ and NEt3 $(167 \mu \mathrm{L}, 1.2 \mathrm{mmol})$. The reaction mixture was stirred at room temperature for $5 \mathrm{~h}$, then worked up by addition of water. The aqueous layer was extracted with EtOAc. The combined organic layer was washed with saturated aqueous $\mathrm{NaHCO}_{3}$ solution, water and brine, then dried over $\mathrm{Na}_{2} \mathrm{SO}_{4}$ and concentrated under reduced pressure. The expected compounds $\mathbf{3 b}$ (428 mg, 75\%) was obtained as a colorless solid, pure enough to be used without further purification. $\mathrm{Mp}: 75.5-77.5^{\circ} \mathrm{C}$. IR (KBr) $v_{\max }: 3331,1640,1564 \mathrm{~cm}^{-1} .{ }^{1} \mathrm{H}$ NMR $(300 \mathrm{MHz}, \mathrm{MeOD})$ $\delta: 7.33(\mathrm{~d}, J=2.1 \mathrm{~Hz}, 1 \mathrm{H}) ; 7.08(\mathrm{dd}, J=2.1,8.4 \mathrm{~Hz}, 1 \mathrm{H}) ; 7.04-7.00(\mathrm{~m}, 2 \mathrm{H}) ; 6.92(\mathrm{~d}$, $J=8.4 \mathrm{~Hz}, 1 \mathrm{H}) ; 6.71-6.66(\mathrm{~m}, 2 \mathrm{H}) ; 3.83(\mathrm{~s}, 3 \mathrm{H}) ; 3.12(\mathrm{t}, J=6.9 \mathrm{~Hz}, 2 \mathrm{H}) ; 2.81(\mathrm{t}, J=$ $7.3 \mathrm{~Hz}, 2 \mathrm{H})$; 2.48-2.49 (m, 4H); 1.68 (q, $J=7.2 \mathrm{~Hz}, 2 \mathrm{H}) .{ }^{13} \mathrm{C}$ NMR (75 MHz, MeOD) $\delta$ : 175.4; 156.8; 136.7; 134.0; 132.8; 130.4; 129.6; 116.2; 113.2; 112.3; 56.7;39.8; 39.2; 32.7; 32.2; 32.1. HRMS ( $\left.\mathrm{DCl}, \mathrm{CH}_{4}\right) \mathrm{m} / \mathrm{z}$ calcd for $\mathrm{C}_{19} \mathrm{H}_{23} \mathrm{NO}_{3} \mathrm{Br}[\mathrm{M}+\mathrm{H}]^{+}: 392.0861$, found: 392.0868 .

4.1.4. tert-butyl (S)-(1-((3-(3-bromo-4-methoxyphenyl)propyl)amino)-3-(4hydroxyphenyl)-1-oxopropan-2-yl)carbamate (10). To a solution of amine 6 (386 mg, $1.6 \mathrm{mmol})$ in anhydrous THF (4 mL) at room temperature were added successively the 
acid 8 (394 mg, $1.4 \mathrm{mmol}), \mathrm{HOBt}(19 \mathrm{mg}, 0.14 \mathrm{mmol})$, EDC (248 mg, $1.6 \mathrm{mmol}$ and $\mathrm{NEt}_{3}(223 \mu \mathrm{L}, 1.4 \mathrm{mmol})$. The reaction mixture was stirred at room temperature for 5 $\mathrm{h}$, then worked up by addition of water. The aqueous layer was extracted with EtOAc. The combined organic layer was washed with saturated aqueous $\mathrm{NaHCO}_{3}$ solution, water and brine, then dried over $\mathrm{Na}_{2} \mathrm{SO}_{4}$ and concentrated under reduced pressure. The expected compounds 10 (676 mg, 83\%) was obtained as a light yellow gum, pure enough to be used without further purification. $[\alpha] \mathrm{D}^{20}=+10.5$ (c 1.0, MeOH). IR (neat) $v_{\max }: 3340,1674 \mathrm{~cm}^{-1} .{ }^{1} \mathrm{H}$ NMR $(300 \mathrm{MHz}, \mathrm{MeOD}) \delta: 7.35(\mathrm{~d}, J=2.1 \mathrm{~Hz}, 1 \mathrm{H}) ; 7.10$ (dd, $J=2.1,8.4 \mathrm{~Hz}, 1 \mathrm{H})$; 7.06-7.03 (m, 2H); $6.93(\mathrm{~d}, J=8.4 \mathrm{~Hz}, 1 \mathrm{H}) ; 6.72-6.68(\mathrm{~m}$, $2 \mathrm{H})$; 4.19-4.14 (m, $1 \mathrm{H})$; $3.83(\mathrm{~s}, 3 \mathrm{H})$; 3.19-3.04 (m, 2H); $2.92(\mathrm{dd}, J=6.9,13.5 \mathrm{~Hz}, 1 \mathrm{H})$; 2.75 (dd, $J=8.1,13.5 \mathrm{~Hz}, 1 \mathrm{H}), 2.49-2.44(\mathrm{~m}, 2 \mathrm{H}) ; 1.73-1.63(\mathrm{~m}, 2 \mathrm{H}) ; 1.39(\mathrm{~s}, 9 \mathrm{H}) .{ }^{13} \mathrm{C}$ NMR (75 MHz, MeOD) $\delta: 174.4 ; 157.5 ; 157.3 ; 155.6 ; 136.7 ; 134.3 ; 131.3 ; 129.6 ; 129.1$; $116.2 ; 113.2 ; 112.3 ; 80.6 ; 57.9 ; 56.6 ; 39.7 ; 38.7 ; 32.7 ; 32.1 ; 23.7$. HRMS ( $\left.\mathrm{DCl}, \mathrm{CH}_{4}\right)$ $\mathrm{m} / \mathrm{z}$ calcd for $\mathrm{C}_{19} \mathrm{H}_{23} \mathrm{NO}_{3} \mathrm{Br}[\mathrm{M}+\mathrm{H}]^{+}: 507.1495$, found: 507.1470 .

4.1.5. tert-butyl (S)-(1-((3-(3-bromo-4-methoxyphenyl)propyl)amino)-3-(4-((tertbutyldimethylsilyl)oxy)phenyl)-1-oxopropan-2-yl)carbamate (11). To a solution of acid 9 (81 $\mathrm{mg}, 0.205 \mathrm{mmol})$ in anhydrous DMF $(1 \mathrm{~mL})$ at room temperature were added successively, HOBt (31 mg, $0.226 \mathrm{mmol}$ ), EDC (35 mg, $0.226 \mathrm{mmol}$ ) and NEt $3(57 \mu \mathrm{L}$, 0.41). After stirring for $15 \mathrm{~min}$, amine 6 (50 mg, $0.205 \mathrm{mmol}$ ) dissolved in DMF ( $1 \mathrm{~mL}$ ) was added. The reaction mixture was stirred at room temperature overnight and worked up by addition of water. The aqueous layer was extracted with EtOAc. The combined organic layer was washed with saturated aqueous $\mathrm{NH}_{4} \mathrm{Cl}$ solution, water and brine, then dried over $\mathrm{Na}_{2} \mathrm{SO}_{4}$ and concentrated under reduced pressure. The crude residue was purified by column chromatography on silica gel $(\mathrm{EtOAc} / \mathrm{PE}=3: 7)$ to provide the expected compound $11(61 \mathrm{mg}, 51 \%)$ as a yellow oil. $[\alpha]_{\mathrm{D}}^{20}=+9.9(\mathrm{c} 1.0$, $\mathrm{CH}_{2} \mathrm{Cl}_{2}$ ). IR (neat) $v_{\max }: 3303,1678,1653 \mathrm{~cm}^{-1} .{ }^{1} \mathrm{H}$ NMR $(300 \mathrm{MHz}, \mathrm{MeOD}) \delta: 7.34$ (d, $J=2.1 \mathrm{~Hz}, 1 \mathrm{H}) ; 7.12-7.08(\mathrm{~m}, 3 \mathrm{H}) ; 6.92(\mathrm{~d}, J=8.4 \mathrm{~Hz}, 1 \mathrm{H}) ; 6.76-6.73(\mathrm{~m}, 2 \mathrm{H}) ; 4.19(\mathrm{t}$, $J=7.2 \mathrm{~Hz}, 1 \mathrm{H}) ; 3.83(\mathrm{~s}, 3 \mathrm{H}) ; 3.21-3.03(\mathrm{~m}, 2 \mathrm{H}) ; 2.96(\mathrm{dd}, J=14.1,7.2 \mathrm{~Hz}, 1 \mathrm{H}) ; 2.77$ (dd, $J=14.1,8.3 \mathrm{~Hz}, 1 \mathrm{H}) ; 2.46-2.43(\mathrm{~m}, 2 \mathrm{H}) ; 1.72-1.61(\mathrm{~m}, 2 \mathrm{H}): 1.39(\mathrm{~s}, 9 \mathrm{H}) ; 0.97(\mathrm{~s}$, $9 \mathrm{H}) ; 0.16$ (s, 6H). ${ }^{13} \mathrm{C}$ NMR (75 MHz, $\left.\mathrm{CDCl}_{3}\right) \delta: 171.3 ; 155.4,154.5 ; 154.0 ; 134.9$; 132.9; 130.2; 129.3; 128.2; 120.1; 111.8; 111.4; 80.1; 56.2 (2C); 38.8; 37.9; 31.7; 30.9; 
28.2; 25.6; 18.1; -4.5. HRMS ( $\left.\mathrm{DCl}, \mathrm{CH}_{4}\right) \mathrm{m} / \mathrm{z}$ calcd for $\mathrm{C}_{30} \mathrm{H}_{46} \mathrm{~N}_{2} \mathrm{O}_{5} \mathrm{SiBr}[\mathrm{M}+\mathrm{H}]^{+}$: 621.2359, found: 621.2369 .

\subsection{6.(S)-2-amino-N-(3-(3-bromo-4-methoxyphenyl)propyl)-3-(4-}

hydroxyphenyl)propanamide(3c). Carbamate 10 (98 mg, $0.193 \mathrm{mmol})$ was dissolved in a $1: 2$ mixture of $12 \mathrm{~N} \mathrm{HCl} /$ dioxane $(1 \mathrm{~mL})$ and the reaction mixture was stirred at $45^{\circ} \mathrm{C}$ for $30 \mathrm{~min}$. The solvant was removed under reduced pressure and the resulting residue dissolved in EtOAc. The organic layer was washed with water and brine, dried over $\mathrm{Na}_{2} \mathrm{SO}_{4}$ and concentrated under reduced pressure to yield the expected compound $3 \mathbf{c}$ ( $76 \mathrm{mg}, 97 \%$ ) as a yellow gum, pure enough to be used without further purification. $[\alpha]_{\mathrm{D}^{20}}^{20}+9$ (c $\left.1.0, \mathrm{MeOH}\right) . \mathrm{IR}$ (neat) $v_{\max }: 3330,2900,1648 \mathrm{~cm}^{-1} \cdot{ }^{1} \mathrm{H}$ NMR (300 MHz, MeOD) $\delta: 7.34(\mathrm{~d}, J=2.1 \mathrm{~Hz}, 1 \mathrm{H}) ; 7.09$ (dd, $J=2.1,8.4 \mathrm{~Hz}, 1 \mathrm{H}) ; 7.01$ 7.04 (m, 2H); 6.93 (d, $J=8.4 \mathrm{~Hz}, 1 \mathrm{H}) ; 6.73-6.69(\mathrm{~m}, 2 \mathrm{H}) ; 3.83(\mathrm{~s}, 3 \mathrm{H}) ; 3.49(\mathrm{t}, J=6.9$ $\mathrm{Hz}, 1 \mathrm{H}$ ); 3.17 (dt, $J=6.9,13.2 \mathrm{~Hz}, 1 \mathrm{H}$ ); 3.08 (dt, $J=6.9,13.5 \mathrm{~Hz}, 1 \mathrm{H}), 2.86$ (dd, $J=$ 6.9, $13.5 \mathrm{~Hz}, 1 \mathrm{H}) ; 2.76(\mathrm{dd}, J=6.9,13.5 \mathrm{~Hz}, 1 \mathrm{H}), 2.47-2.42(\mathrm{~m}, 2 \mathrm{H}) ; 1.72-1.62(\mathrm{~m}$, 2H). ${ }^{13} \mathrm{C}$ NMR (75 MHz, MeOD) $\delta: 174.4 ; 157.2 ; 155.6 ; 136.6 ; 134.0 ; 131.4 ; 129.6$; 128.3; 116.4; 113.3; 112.3; 56.7 (2C); 40.6; 39.8; 32.7; 32.0. HRMS ( $\left.\mathrm{DCl}, \mathrm{CH}_{4}\right) \mathrm{m} / \mathrm{z}$ calcd for $\mathrm{C}_{19} \mathrm{H}_{24} \mathrm{~N}_{2} \mathrm{O}_{3} \mathrm{Br}[\mathrm{M}+\mathrm{H}]^{+}: 407.0970$, found: 407.0970 .

\subsection{7. (S)-3-(3-(3-bromo-4-methoxyphenyl)propyl)-5-(4-((tert-butyldimethylsilyl)oxy)} benzyl)imidazolidine-2,4-dione(12). To a solution of amide 11 (212 $\mathrm{mg}, 0.34 \mathrm{mmol})$ in $\mathrm{CH}_{2} \mathrm{Cl}_{2}(4 \mathrm{~mL})$ at $0^{\circ} \mathrm{C}$ was added pyridine $(80 \mu \mathrm{L}, 1 \mathrm{mmol}) . \mathrm{Tf}_{2} \mathrm{O}(86 \mu \mathrm{L}, 0.51 \mathrm{mmol})$ was added slowly and the reaction mixture was allowed to warm to room temperature. After stirring for $1 \mathrm{~h}$, saturated aqueous $\mathrm{NaHCO}_{3}$ solution was added. The aqueous layer was extracted with $\mathrm{CH}_{2} \mathrm{Cl}_{2}$. The combined organic layer was washed with aqueous saturated $\mathrm{NaHCO}_{3}$ solution, water and brine then dried over $\mathrm{Na}_{2} \mathrm{SO}_{4}$ and concentrated under reduced pressure. Silica gel column chromatography $\left(\mathrm{CH}_{2} \mathrm{Cl} / \mathrm{MeOH}=99: 1\right)$ provided pure hydantoin $12(152 \mathrm{mg}, 81 \%)$ as an orange gum. $[\alpha]_{D^{20}}=-67.9\left(\mathrm{c} 1.0, \mathrm{CH}_{2} \mathrm{Cl}_{2}\right)$. IR (neat) $v_{\max }: 3286,1710 \mathrm{~cm}^{-1} .{ }^{1} \mathrm{H} \mathrm{NMR}(300 \mathrm{MHz}$, $\left.\mathrm{CDCl}_{3}\right) \delta: 7.36(\mathrm{~d}, J=2.2 \mathrm{~Hz}, 1 \mathrm{H}) ; 7.07(\mathrm{dd}, \mathrm{J}=8.3,2.2 \mathrm{~Hz}, 1 \mathrm{H}) ; 7.05-7.02(\mathrm{~m}, 2 \mathrm{H}) ; 6.81$ (d, $J=8.3 \mathrm{~Hz}, 1 \mathrm{H}) ; 6.79-6.76(\mathrm{~m}, 2 \mathrm{H}) ; 5.19$ (brs, NH); 4.15 (ddd, $J=8.7,3.7 \mathrm{~Hz}, J=1.2$ $\mathrm{Hz}, 1 \mathrm{H}) ; 3.9(\mathrm{~s}, 3 \mathrm{H}) ; 3.46(\mathrm{td}, J=7.4,2.1 \mathrm{~Hz}, 2 \mathrm{H}) ; 3.18(\mathrm{dd}, J=14.2,3.8 \mathrm{~Hz}, 1 \mathrm{H}) ; 2.73$ 
(dd, $J=14.2,8.6 \mathrm{~Hz}, 1 \mathrm{H}) ; 2.52-2.47(\mathrm{~m}, 2 \mathrm{H}) ; 1.88-1.78(\mathrm{~m}, 2 \mathrm{H}): 0.96(\mathrm{~s}, 9 \mathrm{H}) ; 0.16(\mathrm{~s}$, $6 \mathrm{H}) .{ }^{13} \mathrm{C}$ NMR $\left(75 \mathrm{MHz}, \mathrm{CDCl}_{3}\right) \delta: 173.1 ; 157.0,155.0 ; 154.1 ; 134.6 ; 133.0 ; 130.3$; $128.2 ; 127.6 ; 120.4 ; 111.9 ; 111.4 ; 58.3 ; 56.2 ; 38.1 ; 37.0 ; 31.6 ; 29.2 ; 25.6 ; 18.1 ;-4.5$. HRMS (DCl, $\left.\mathrm{CH}_{4}\right) \mathrm{m} / \mathrm{z}$ calcd for $\mathrm{C}_{26} \mathrm{H}_{36} \mathrm{~N}_{2} \mathrm{O}_{4} \mathrm{SiBr}[\mathrm{M}+\mathrm{H}]^{+}: 547.1628$, found : 547.1619 .

4.1.8. 3-(3-(3-bromo-4-methoxyphenyl)propyl)-5-(4-hydroxybenzyl)imidazolidine-2,4dione (1d). To a solution of compound $12(95 \mathrm{mg}, 0.17 \mathrm{mmol})$ in anhydrous THF (4 $\mathrm{mL}$ ) at $0^{\circ} \mathrm{C}$ was added TBAF ( $1 \mathrm{M}$ in THF, $\left.0.35 \mathrm{~mL}, 0.35 \mathrm{mmol}\right)$. The reaction mixture was stirred at $0^{\circ} \mathrm{C}$ for $10 \mathrm{~min}$ and quenched with saturated aqueous $\mathrm{NaHCO}_{3}$ solution. The aqueous layer was extracted with EtOAc and the combined organic layer was washed with saturated aqueous $\mathrm{NaHCO}_{3}$ solution, water and brine, dried over $\mathrm{Na}_{2} \mathrm{SO}_{4}$ and concentrated under vacuum. Silica gel column chromatography $\left(\mathrm{CH}_{2} \mathrm{Cl}_{2} / \mathrm{MeOH}=\right.$ 97:3) afforded pure phenol $1 \mathrm{~d}$ (56 mg, 75\%). $[\alpha]_{\mathrm{D}^{20}}=-84.7^{\circ}\left(\mathrm{c} 1.0, \mathrm{CH}_{2} \mathrm{Cl}_{2}\right)$. IR (neat) $v_{\max }: 3300,1766,1696 \mathrm{~cm}^{-1} .{ }^{1} \mathrm{H} \mathrm{NMR}\left(300 \mathrm{MHz}, \mathrm{CDCl}_{3}\right) \delta: 7.33(\mathrm{~d}, \mathrm{~J}=2.2 \mathrm{~Hz}, 1 \mathrm{H})$; 7.07-7.04 (m, 3H); 6.81 (d, J = 8.5 Hz, 1H); 6.77-6.74 (m, 2H); 5.21 (brs, NH); 4.85 (s, $\mathrm{OH}$ ); 4.17 (ddd, $J=7.9,3.9,1.3 \mathrm{~Hz}, 1 \mathrm{H}) ; 3.87$ (s, 3H); 3.47 (m, 2H); 3.14 (dd, $J=14.2$, $3.9 \mathrm{~Hz}, 1 \mathrm{H}) ; 2.81(\mathrm{dd}, J=14.3,7.9 \mathrm{~Hz}, 1 \mathrm{H}) ; 2.51-2.30(\mathrm{~m}, 2 \mathrm{H}) ; 1.87-1.67(\mathrm{~m}, 2 \mathrm{H}) .{ }^{13} \mathrm{C}$ $\operatorname{NMR}\left(75 \mathrm{MHz}, \mathrm{CDCl}_{3}\right) \delta: 173.5 ; 157.8 ; 155.4 ; 154.2 ; 134.8 ; 133.1 ; 130.9 ; 128.4 ; 126.3$; $115.8 ; 112.1 ; 111.5 ; 58.4 ; 56.4 ; 38.3 ; 36.6 ; 31.6 ; 29.4$. HRMS $\left(\mathrm{DCl}, \mathrm{CH}_{4}\right) \mathrm{m} / \mathrm{z}$ calcd for $\mathrm{C}_{20} \mathrm{H}_{22} \mathrm{~N}_{2} \mathrm{O} 4 \mathrm{Br}[\mathrm{M}+\mathrm{H}]^{+}:$433.0763, found: 433.0756 .

4.1.9. 1-(3-bromo-4-methoxyphenethyl)-4-(4-((tert-butyldimethylsilyl)oxy)phenethyl)$1 \mathrm{H}-1,2,3$-triazole (15). To a solution of alcyne 14 [31] (540 mg, $2.07 \mathrm{mmol}$ ) in a 1/1 THF- $\mathrm{H}_{2} \mathrm{O}$ mixture $(14 \mathrm{~mL})$ were added successively sodium ascorbate $(206 \mathrm{mg}, 1.03$ $\mathrm{mmol}$ ), $\mathrm{CuSO}_{4} .5 \mathrm{H}_{2} \mathrm{O}(103 \mathrm{mg}, 0.41 \mathrm{mmol}$ ) and a solution of azide 13 [30] (532 mg, $2.07 \mathrm{mmol})$ in a $1 / 1 \mathrm{THF}-\mathrm{H}_{2} \mathrm{O}$ mixture $(4 \mathrm{~mL})$. The reaction mixture was stirred overnight at room temperature. Water was then added and the aqueous layer was extracted with EtOAc. The combined organic layer was washed with water and brine, dried over $\mathrm{Na}_{2} \mathrm{SO}_{4}$ and concentrated under vacuum. Silica gel column chromatography (EtOAc/PE = 3:7) provided triazole $15(892 \mathrm{mg}, 83.3 \%)$ as a colorless solid. $\mathrm{Mp}$ : $102^{\circ} \mathrm{C}$. IR (neat) $v_{\max }: 1605 \mathrm{~cm}^{-1} .{ }^{1} \mathrm{H} \mathrm{NMR}\left(300 \mathrm{MHz}, \mathrm{CD}_{3} \mathrm{CN}\right) \delta: 7.30(\mathrm{~d}, J=2.0 \mathrm{~Hz}$, $1 \mathrm{H}) ; 7.22(\mathrm{~s}, 1 \mathrm{H}) ; 7.06-7.02(\mathrm{~m}, 2 \mathrm{H}) ; 7.01$ (dd, $J=2.0,8.4 \mathrm{~Hz}, 1 \mathrm{H}) ; 6.90(\mathrm{~d}, J=8.4 \mathrm{~Hz}$, 
1H); 6.78-6.73 (m, 2H); $4.47(\mathrm{t}, J=7 . \mathrm{Hz}, 2 \mathrm{H}) ; 3.05(\mathrm{t}, J=7.0 \mathrm{~Hz}, 2 \mathrm{H}) ; 2.93-2.79(\mathrm{~m}$, $4 \mathrm{H}) ; 0.97$ (s, 9H); 0.17 (s, 6H). ${ }^{13} \mathrm{C} \mathrm{NMR}\left(75 \mathrm{MHz}, \mathrm{CDCl}_{3}\right) \delta: 154.9 ; 153.9 ; 147.1 ; 133.9$; 133.4; 130.7; 129.4; 128.8; 121.4; 119.9; 112.1; 111.7; 56.3; 51.4; 35.6; 34.8; 27.6; 25.7; 18.2; -4.4. HRMS (DCl, $\left.\mathrm{CH}_{4}\right) \mathrm{m} / \mathrm{z}$ calcd for $\mathrm{C}_{25} \mathrm{H}_{35} \mathrm{~N}_{3} \mathrm{O}_{2} \mathrm{Br}[\mathrm{M}+\mathrm{H}]^{+}: 516.1682$, found: 516.1661 .

4.1.10. 4-(2-(1-(3-bromo-4-methoxyphenethyl)-1H-1,2,3-triazol-4-yl)ethyl)phenol (3e).To a solution of triazole $15(890 \mathrm{mg}, 1.72 \mathrm{mmol})$ in anhydrous THF $(20 \mathrm{~mL})$ at $0^{\circ} \mathrm{C}$ was added TBAF ( $1 \mathrm{M}$ in THF, $3.45 \mathrm{~mL}, 3.45 \mathrm{mmol}$ ). The reaction mixture was stirred at $0^{\circ} \mathrm{C}$ for $3 \mathrm{~h}$ and quenched with saturated aqueous $\mathrm{NaHCO}_{3}$ solution. The aqueous layer was extracted with EtOAc and the combined organic layer was washed with saturated aqueous $\mathrm{NaHCO}_{3}$ solution, water and brine, dried over $\mathrm{Na}_{2} \mathrm{SO}_{4}$ and concentrated under reduce pressure. Pure phenol 3 e (574 mg, 83\%) was obtained by recrystallization in $\mathrm{MeOH}$ as a colorless solid. $\mathrm{Mp}: 140^{\circ} \mathrm{C}$. IR (neat) $v_{\max }: 3432,1613$ $\mathrm{cm}^{-1} .{ }^{1} \mathrm{H}$ NMR (300 MHz, DMSO- $\left.d_{6}\right) \delta: 9.14(\mathrm{~s}, 1 \mathrm{H}) ; 7.68(\mathrm{~s}, 1 \mathrm{H}) ; 7.39(\mathrm{~d}, J=2.1 \mathrm{~Hz}$, $1 \mathrm{H}) ; 7.07$ (dd, $J=2.1,8.4 \mathrm{~Hz}, 1 \mathrm{H}) ; 6.99-6.95(\mathrm{~m}, 3 \mathrm{H}) ; 6.69-6.61(\mathrm{~m}, 2 \mathrm{H}) ; 4.49$ (t, $J=$ $7.1 \mathrm{~Hz}, 2 \mathrm{H}) ; 3.80$ (s, 3H); 3.05 (t, $J=7.1 \mathrm{~Hz}, 2 \mathrm{H}) ; 2.82-2.76(\mathrm{~m}, 4 \mathrm{H}) .{ }^{13} \mathrm{C}$ NMR $(75$ $\mathrm{MHz}$, DMSO-d $\left.d_{6}\right) \delta$ : $155.4 ; 154.0 ; 146.2 ; 133.0 ; 131.4 ; 131.3 ; 129.2 ; 129.1 ; 121.9$; $115.0 ; 112.5 ; 110.4 ; 56.1 ; 50.3 ; 34.4 ; 34.2 ; 27.3$. HRMS $\left(\mathrm{DCl} \mathrm{CH}_{4}\right) \mathrm{m} / \mathrm{z}$ calcd for $\mathrm{C}_{19} \mathrm{H}_{21} \mathrm{~N}_{3} \mathrm{O}_{2} \mathrm{Br}[\mathrm{M}+\mathrm{H}]^{+}:$402.0817, found: 402.0803 .

4.1.11. Ullmann cyclisation: General procedure for the synthesis of compounds $2 \boldsymbol{2 b}, \mathbf{2 c}$ and $2 e$.

A mixture of phenol ( 1 equiv), $\mathrm{K}_{2} \mathrm{CO}_{3}$ (2 equiv) and $\mathrm{CuO}$ (2.5 equiv) in dry pyridine (2 $10^{-2} \mathrm{M}$ ) was heated at $150^{\circ} \mathrm{C}$ under microwave irradiation in a sealed tube. The reaction mixture was cooled to rt and concentrated under reduced pressure. The residue was dissolved in EtOAc and neutralized by addition of $10 \%$ aqueous $\mathrm{NaHSO}_{3}$ solution. The aqueous layer was extracted with EtOAc and the combined organic layers were washed with $10 \%$ aqueous $\mathrm{NaHSO}_{3}$ solution, water and brine, then dried over $\mathrm{Na}_{2} \mathrm{SO}_{4}$ and concentrated under reduced pressure. The crude residue was purified by silica gel column chromatography to provide the expected compound. 
4.1.11.1. 16-methoxy-2-oxa-7-aza-1(1,3),3(1,4)-dibenzenacyclodecaphan-6-one (2b). Following the general procedure, phenol $3 \mathbf{b}\left(31 \mathrm{mg}, 810^{-2} \mathrm{mmol}\right)$ was heated for $5 \mathrm{~h}$. Silica gel column chromatography $\left(\mathrm{CH}_{2} \mathrm{Cl}_{2} / \mathrm{MeOH}=98: 2\right)$ afforded pure compound $\mathbf{2 b}$ (20 mg, 80\% yield) as a colorless solid. $\mathrm{Mp}: 166-168{ }^{\circ} \mathrm{C}$. IR (neat) $v_{\max }: 3280,1671$ $\mathrm{cm}^{-1} .{ }^{1} \mathrm{H}$ NMR (300 MHz, MeOD) 8: 7.27-7.23 (m, 2H); 6.99-6.95 (m, 2H); 6.89 (d, $J=$ $8.1 \mathrm{~Hz}, 1 \mathrm{H}) ; 6.66(\mathrm{dd}, J=8.1,2.1 \mathrm{~Hz}, 1 \mathrm{H}) ; 5.48(\mathrm{~d}, J=2.1 \mathrm{~Hz}, 1 \mathrm{H}) ; 3.90(\mathrm{~s}, 3 \mathrm{H}) ; 2.99$ 2.95 (m, 2H); 2.73 (t, J = 6.9 Hz, 2H); 2.52-2.48 (m, 2H); 2.44-2.40 (m, 2H); 1.62 (q, J $=6.6 \mathrm{~Hz}, 2 \mathrm{H}) .{ }^{13} \mathrm{C}$ NMR $(75 \mathrm{MHz}, \mathrm{MeOD}) \delta: 175.2 ; 157.5 ; 152.8 ; 147.9 ; 138.9 ; 134.5$; $132.0 ; 124.4 ; 122.8 ; 117.2 ; 114.1 ; 56.9 ; 39.8 ; 39.4 ; 32.9 ; 30.3 ; 27.6$. HRMS (DCl, $\left.\mathrm{CH}_{4}\right)$ $\mathrm{m} / \mathrm{z}$ calcd for $\mathrm{C}_{19} \mathrm{H}_{22} \mathrm{NO}_{3}[\mathrm{M}+\mathrm{H}]^{+}: 312.1600$, found: 312.1595 .

\subsubsection{2.(S)-5-amino-16-methoxy-2-oxa-7-aza-1(1,3),3(1,4)-}

dibenzenacyclodecaphan-6-one (2c). Following the general procedure, phenol 3c (62 $\mathrm{mg}, 1.410^{-4} \mathrm{mmol}$ ) was heated for $30 \mathrm{~min}$. Silica gel column chromatography $\left(\mathrm{CH}_{2} \mathrm{Cl}_{2} / \mathrm{MeOH}=92: 8\right)$ afforded pure compound $2 \mathrm{c}$ (19 $\mathrm{mg}, 41 \%$ yield) as a yellow gum. $[\alpha]_{D^{20}}=-43.9$ ( c 1.0, MeOH). IR (neat) $v_{\max }: 3343,3328,1658 \mathrm{~cm}^{-1} .{ }^{1} \mathrm{H}$ NMR (300 MHz, MeOD) $\delta: 7.35$ (dd, $J=8.4,2.2 \mathrm{~Hz}, 1 \mathrm{H}) ; 7.19(\mathrm{dd}, J=8.2,2.5 \mathrm{~Hz}, 1 \mathrm{H}) ; 7.10$ (dd, $J=8.3,2.2 \mathrm{~Hz}, 1 \mathrm{H}) ; 6.91(\mathrm{~d}, J=8.3 \mathrm{~Hz}, 1 \mathrm{H}) ; 6.79(\mathrm{dd}, J=8.3,2.4 \mathrm{~Hz}, 1 \mathrm{H}) ; 6.68$ (dd, $J=8.2,2.2 \mathrm{~Hz}, 1 \mathrm{H}$ ); 5.53 (d, $J=2.1 \mathrm{~Hz}, 1 \mathrm{H}$ ); 3.90 (s, 3H); 3.64 (brs, NH); 3.51 (dd, $J=10.6,5.5 \mathrm{~Hz}, 1 \mathrm{H}$ ); 3.16 (dd, $J=12.2,5.5 \mathrm{~Hz}, 1 \mathrm{H}$ ); 3.06 (dt, $J=13.8,7.9 \mathrm{~Hz}$, $1 \mathrm{H}$ ); 2.69 (dd, $J=12.2,10.6 \mathrm{~Hz}, 1 \mathrm{H}$ ); 2.62 (ddd, $J=16.0,8.0 \mathrm{~Hz}, 3.1 \mathrm{~Hz}, 1 \mathrm{H}$ ); 2.49 $4.31(\mathrm{~m}, 1 \mathrm{H}) ; 2.41-2.32(\mathrm{~m}, 1 \mathrm{H}) ; 1.85-1.70(\mathrm{~m}, 1 \mathrm{H}) ; 1.64-1.46(\mathrm{~m}, 1 \mathrm{H}) .{ }^{13} \mathrm{C}$ NMR $(75$ $\mathrm{MHz}, \mathrm{MeOD}) \delta: 176.0 ; 158.1,152.7 ; 148.0 ; 135.7$; 134.0; 133.2; 131.4; 124.8; 124.2; $123.1 ; 117.3 ; 114.3 ; 58.8 ; 56.9 ; 42.738 .9 ; 29.9 ; 26.6$. HRMS $\left(\mathrm{DCl}, \mathrm{CH}_{4}\right) \mathrm{m} / \mathrm{z}$ calcd for $\mathrm{C}_{19} \mathrm{H}_{22} \mathrm{~N}_{2} \mathrm{O}_{3}[\mathrm{M}]^{+}: 326.1630$, found : 326.1622 .

4.1.11.3.

(Z)-16-methoxy-6 ${ }^{1}$ H-2-oxa-6(4,1)-triazola-1 $(1,3), 3(1,4)$ dibenzenacyclooctaphane (2e). Following the general procedure, phenol $3 \mathbf{e}(30 \mathrm{mg}$, $7.410^{-5} \mathrm{mmol}$ ) was heated for $5 \mathrm{~h}$. Silica gel column chromatography (EtOAc) afforded pure compound $2 \mathbf{e}\left(17 \mathrm{mg}, 71 \%\right.$ yield) as a colorless solid. $\mathrm{Mp}=159-161^{\circ} \mathrm{C} .[\alpha]_{\mathrm{D}}^{20}=$ +4 (c 0.5, MeOH). IR (neat) $v_{\max }: 1606 \mathrm{~cm}^{-1}$. ${ }^{1} \mathrm{H}$ NMR $\left(300 \mathrm{MHz}\right.$, DMSO-d $\left.d_{6}\right) \delta: 7.25$ (s, $1 \mathrm{H}) ; 7.09(\mathrm{~d}, J=8.4 \mathrm{~Hz}, 2 \mathrm{H}) ; 6.91(\mathrm{~d}, J=8.2 \mathrm{~Hz}, 1 \mathrm{H}) ; 6.76(\mathrm{~d}, J=8.2 \mathrm{~Hz}, 2 \mathrm{H}) ; 6.74$ (dd, $J=2.2,8.2 \mathrm{~Hz}, 1 \mathrm{H}) ; 4.80(\mathrm{~d}, J=2.0 \mathrm{~Hz}, 1 \mathrm{H}) ; 4.25-4.42(\mathrm{~m}, 2 \mathrm{H}) ; 3.80(\mathrm{~s}, 3 \mathrm{H})$; 
3.09-3.01 (m, 4H); 2.96-2.92 (m, 2H). ${ }^{13} \mathrm{C}$ NMR (75 MHz, DMSO- $\left.d_{6}\right) \delta: 153.8 ; 150.7$; 146.9; 140.6; 138.0; 131.6; 131.0; 124.4; 122.7; 122.0; 115.2; 112.4; 55.7; 50.4; 32.8; 32.4; 25.8. HRMS (DCl, $\left.\mathrm{CH}_{4}\right) \mathrm{m} / \mathrm{z}$ calcd for $\mathrm{C}_{19} \mathrm{H}_{20} \mathrm{~N}_{3} \mathrm{O}_{2}[\mathrm{M}+\mathrm{H}]^{+}: 322.1556$, found: 322.1560 .

4.1.12.

(14S)-56-methoxy-4-oxa-1 (4,1)-imidazolidina-3(1,4),5(1,3)dibenzenacyclooctaphane-12,15-dione (2d). A mixture of phenol 3d (35 mg), NaH (5 $\mathrm{mg}$ ) and CuBr.DMS (164 mg) in dry pyridine $(4 \mathrm{~mL})$ was heated at $150^{\circ} \mathrm{C}$ under microwave irradiation in a sealed tube for $30 \mathrm{~min}$. The reaction mixture was cooled to rt and concentrated under reduced pressure. The residue was dissolved in EtOAc and neutralized by addition of $10 \%$ aqueous $\mathrm{NaHSO}_{3}$ solution. The aqueous layer was extracted with EtOAc and the combined organic layers were washed with 10\% aqueous $\mathrm{NaHSO}_{3}$ solution, water and brine, then dried over $\mathrm{Na}_{2} \mathrm{SO}_{4}$ and concentrated under reduced pressure. The crude residue was purified by silica gel column chromatography $\left(\mathrm{CH}_{2} \mathrm{Cl}_{2} / \mathrm{MeOH}=97: 3\right)$ to provide the expected compound $\mathbf{2 d}$ ( $15 \mathrm{mg}$, $53 \%$ yield) as a yellow gum. $[\alpha]_{\mathrm{D}^{20}}=+63.8\left(\mathrm{c} 1.0, \mathrm{CH}_{2} \mathrm{Cl}_{2}\right)$. IR (neat) $v_{\max }: 3300,1756$, $1696 \mathrm{~cm}^{-1}$. ${ }^{1} \mathrm{H}$ NMR (300 MHz, MeOD) $\delta: 7.37$ (dd, $J=8.2,2.2 \mathrm{~Hz}, 1 \mathrm{H}$ ); 7.28 (dd, $J=$ 8.3, 2.2 Hz, $1 \mathrm{H}$ ); 7.09 (dd, $J=8.2,2.5 \mathrm{~Hz}, 1 \mathrm{H}) ; 6.87(\mathrm{dd}, J=8.3,2.5 \mathrm{~Hz}, 1 \mathrm{H}) ; 6.75(\mathrm{~d}$, $J=8.0 \mathrm{~Hz}, 1 \mathrm{H}) ; 6.55(\mathrm{dd}, J=8.0,2.1 \mathrm{~Hz}, 1 \mathrm{H}) ; 4.71(\mathrm{~d}, J=2.1 \mathrm{~Hz}, 1 \mathrm{H}) ; 4.44(\mathrm{dd}, J=$ 4.2, 3.2 Hz, $1 \mathrm{H}$ ); 3.87 (s, 3H); 3.44 (ddd, $J=14.1,5.3,2.1 \mathrm{~Hz}, 1 \mathrm{H}$ ); 3.36 (dd, $J=14.1$, $3.2 \mathrm{~Hz}, 1 \mathrm{H}$ ); 3.18 (ddd, $J=14.0,12.8,1.5 \mathrm{~Hz}, 1 \mathrm{H}$ ); 3.14 (dd, $J=14.3,4.2 \mathrm{~Hz}, 1 \mathrm{H}$ ); 2.54 (dd, $J=13.8,8.4 \mathrm{~Hz}, 1 \mathrm{H}$ ); 2.40 (ddd, $J=14.4,10.2,8.2 \mathrm{~Hz}, 1 \mathrm{H}$ ); 2.07-1.93 (m, $1 \mathrm{H}) ; 0.96-0.83(\mathrm{~m}, 1 \mathrm{H}) .{ }^{13} \mathrm{C}$ NMR (75 MHz, MeOD) $\delta: 175.5 ; 159.8 ; 158.6 ; 153.7 ; 147.4$; 137.1; 133.8; 133.1; 133.0; 125.0; 124.4; 121.0; 118.4; 112.9; 59.6; 56.8; 40.9; 35.9; 33.9; 33.2. HRMS $\left(\mathrm{DCl}, \mathrm{CH}_{4}\right) \mathrm{m} / \mathrm{z}$ calcd for $\mathrm{C}_{20} \mathrm{H}_{21} \mathrm{~N}_{2} \mathrm{O}_{4}[\mathrm{M}+\mathrm{H}]^{+}: 353.1501$, found: 353.1487.

\subsubsection{O-demethylation: General procedure for the synthesis of compounds $\mathbf{1 b}$-e.}

To a solution of the O-methylated derivative (1 equiv) in anhydrous $\mathrm{CH}_{2} \mathrm{Cl}_{2}$ at $-78^{\circ} \mathrm{C}$ was added dropwise $\mathrm{BBr}_{3}(1 \mathrm{M}$ in hexane, 10 equiv). The reaction mixture was allowed to warm to $0^{\circ} \mathrm{C}$, stirred for 1 to $4 \mathrm{~h}$, and then quenched with ice water. The aqueous 
layer was extracted with $\mathrm{CH}_{2} \mathrm{Cl}_{2}$. The combined organic layer was washed with water, brine and dried over $\mathrm{Na}_{2} \mathrm{SO}_{4}$ and concentrated under reduced pressure.

4.1.13.1. 16-hydroxy-2-oxa-7-aza-1(1,3),3(1,4)-dibenzenacyclodecaphan-6-one(1b). Following the general procedure, compound $\mathbf{2 b}\left(72 \mathrm{mg}, 0.23 \mathrm{mmol}\right.$ was stirred at $0^{\circ} \mathrm{C}$ for $4 \mathrm{~h}$. Silica gel column chromatography $\left(\mathrm{CH}_{2} \mathrm{Cl}_{2} / \mathrm{MeOH}=96: 4\right)$ afforded pure compound $1 \mathrm{~b}$ (44 $\mathrm{mg}, 48 \%$ yield) as a beige solid. $[\alpha]_{\mathrm{D}}^{20}=+0.85$ (c $0.48, \mathrm{MeOH}$ ). Mp $>200^{\circ} \mathrm{C}$. IR (neat) $v_{\max }: 3300,1622 \mathrm{~cm}^{-1} .{ }^{1} \mathrm{H} \mathrm{NMR}(300 \mathrm{MHz}, \mathrm{MeOD}) \delta: 7.26-7.22(\mathrm{~m}$, $2 \mathrm{H}) ; 7.0-6.97(\mathrm{~m}, 2 \mathrm{H}) ; 6.73(\mathrm{~d}, J=8.1 \mathrm{~Hz}, 1 \mathrm{H}) ; 6.55(\mathrm{dd}, J=8.1,2.1 \mathrm{~Hz}, 1 \mathrm{H}) ; 5.48(\mathrm{~d}$, $J=2.1 \mathrm{~Hz}, 1 \mathrm{H})$; 2.99-2.95 (m, 2H); $2.71(\mathrm{t}, J=7.1 \mathrm{~Hz}, 2 \mathrm{H})$; 2.50-2.46 (m, $2 \mathrm{H})$; $1.66-$ $1.57(\mathrm{~m}, 2 \mathrm{H}) ; 1.62$ (q, $J=6.6 \mathrm{~Hz}, 2 \mathrm{H}) .{ }^{13} \mathrm{C}$ NMR (75 MHz, MeOD) $\delta: 175.2 ; 157.8$; 151.3; 144.8; 138.7; 132.8; 131.8; 124.4; 123.0; 117.3; 117.1; 39.8; 39.3; 32.9; 30.2; 27.2. HRMS (DCl, $\left.\mathrm{CH}_{4}\right) \mathrm{m} / \mathrm{z}$ calcd for $\mathrm{C}_{18} \mathrm{H}_{20} \mathrm{NO}_{3}[\mathrm{M}+\mathrm{H}]^{+}: 298.1443$, found: 298.1438 .

\subsubsection{2.}

(S)-5-amino-16-hydroxy-2-oxa-7-aza-1(1,3),3(1,4)dibenzenacyclodecaphan-6-one(1c). Following the general procedure, compound 2c (29 mg, $0.089 \mathrm{mmol}$ ) was stirred at $0^{\circ} \mathrm{C}$ for $2 \mathrm{~h}$. Silica gel column chromatography $\left(\mathrm{CH}_{2} \mathrm{Cl}_{2} / \mathrm{MeOH}=90: 10\right)$ afforded pure compound $1 \mathrm{c}(19 \mathrm{mg}, 68 \%$ yield $)$ as a light yellow gum. $[\alpha]_{D^{20}}=-38.4(\mathrm{c} 1.0, \mathrm{MeOH})$. IR (neat) $v_{\max }: 3411,3281,1648 \mathrm{~cm}^{-1} .{ }^{1} \mathrm{H}$ NMR (300 MHz,MeOD) $\delta: 7.35$ (dd, $J=8.3,2.2 \mathrm{~Hz}, 1 \mathrm{H}$ ); 7.15 (dd, $J=8.5,2.1 \mathrm{~Hz}, 1 \mathrm{H}$ ); $7.11(\mathrm{dd}, J=8.2,2.5 \mathrm{~Hz}, 1 \mathrm{H}) ; 6.81(\mathrm{dd}, J=8.3,2.5 \mathrm{~Hz}, 1 \mathrm{H}) ; 6.76(\mathrm{~d}, J=8.1 \mathrm{~Hz}, 1 \mathrm{H})$; $6.56(\mathrm{dd}, J=8.1,2.1 \mathrm{~Hz}, 1 \mathrm{H}) ; 5.52(\mathrm{~d}, J=2.1 \mathrm{~Hz}, 1 \mathrm{H}) ; 3.60-3.50(\mathrm{~m}, 1 \mathrm{H}) ; 3.18(\mathrm{dd}, J$ $=12.2,5.6 \mathrm{~Hz}, 1 \mathrm{H}) ; 3.07(\mathrm{dt}, J=13.7,7.8 \mathrm{~Hz}, 1 \mathrm{H}) ; 2.71(\mathrm{dd}, J=11.9,10.7 \mathrm{~Hz}, 1 \mathrm{H})$; 2.60 (ddd, $J=16.2,7.7,3.1 \mathrm{~Hz}, 1 \mathrm{H}$ ); 2.44 (dd, $J=10.0,3.1 \mathrm{~Hz}, 1 \mathrm{H}$ ); 2.43-2.29 (m,

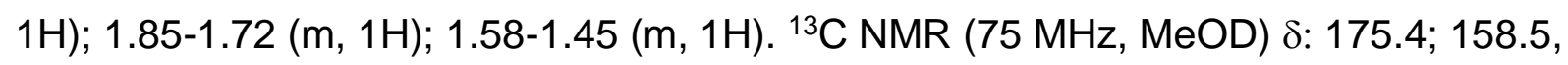
$151.3 ; 145.1 ; 135.4 ; 133.2 ; 132.4 ; 131.2 ; 124.9 ; 124.4 ; 123.4 ; 117.6 ; 117.3 ; 58.5 ; 42.2$; 38.9; 29.8; 26.4. HRMS (DCl, $\left.\mathrm{CH}_{4}\right) \mathrm{m} / \mathrm{z}$ calcd for $\mathrm{C}_{18} \mathrm{H}_{20} \mathrm{~N}_{2} \mathrm{O}_{3}[\mathrm{M}+\mathrm{H}]^{+}: 313.1552$, found : 313.1567.

4.1.13.3.

$\left(1^{4} S\right)$-56-hydroxy-4-oxa-1 (4, 1)-imidazolidina-3(1,4),5(1,3)dibenzenacyclooctaphane-12,15-dione(1d). Following the general procedure, compound $2 \mathrm{~d}$ (31 $\mathrm{mg}, 0.088 \mathrm{mmol}$ ) was stirred at $0^{\circ} \mathrm{C}$ for $1 \mathrm{~h}$. Silica gel column chromatography $\left(\mathrm{CH}_{2} \mathrm{Cl}_{2} / \mathrm{MeOH}=97: 3\right)$ afforded pure compound $1 \mathrm{~d}(14 \mathrm{mg}, 47 \%$ yield) as a colorless solid. $\mathrm{Mp}: 173-175^{\circ} \mathrm{C} .[\alpha]^{20}=+35$ (c $\left.0.32, \mathrm{MeOH}\right)$. IR (neat) $v_{\max }$ 
: 3262, $1710 \mathrm{~cm}^{-1} .{ }^{1} \mathrm{H}$ NMR $\left(300 \mathrm{MHz}, \mathrm{DMSO}-d_{6}\right) \delta: 9.17(\mathrm{~s}, \mathrm{OH}) ; 8.27(\mathrm{~s}, \mathrm{NH}) ; 7.36$ (dd, J = 8.2, $2.0 \mathrm{~Hz}, 1 \mathrm{H}$ ); 7.19 (dd, J = 8.4, 2.0 Hz, 1H); 7.11 (dd, J=8.2, $2.5 \mathrm{~Hz}, 1 \mathrm{H}$ ); $6.90(\mathrm{dd}, J=8.4,2.5 \mathrm{~Hz}, 1 \mathrm{H}) ; 6.58(\mathrm{~d}, J=7.8 \mathrm{~Hz}, 1 \mathrm{H}) ; 6.40(\mathrm{~d}, \mathrm{~J}=7.8 \mathrm{~Hz}, 1 \mathrm{H}) ; 5.54$ (bs, $1 \mathrm{H}) ; 4.44$ (t, J=2.7 Hz, NH); 3.27-3.18 (m, 2H); 3.06-2.98 (m, 2H); 2.46-2.25 (m, $2 \mathrm{H}) ; 2.02-1.86(\mathrm{~m}, 1 \mathrm{H}) ; 0.81-0.65(\mathrm{~m}, 1 \mathrm{H}) .{ }^{13} \mathrm{C}$ NMR $(75 \mathrm{MHz}$, DMSO-d6) $\delta: 173.2$; $157.2 ; 156.4 ; 151.0 ; 143.1 ; 133.5 ; 132.4 ; 131.9 ; 131.8 ; 123.7 ; 123.2 ; 119.9 ; 116.7$; $115.2 ; 57.5 ; 39.2 ; 34.4 ; 32.4 ; 31.5$. HRMS (DCl, $\left.\mathrm{CH}_{4}\right) \mathrm{m} / \mathrm{z}$ calcd for $\mathrm{C}_{19} \mathrm{H}_{19} \mathrm{~N}_{2} \mathrm{O}_{4}[\mathrm{M}+\mathrm{H}]^{+}$: 339.1345, found 339.1336 .

4.1.13.4. (Z)-6'H-2-oxa-6(4,1)-triazola-1(1,3),3(1,4)-dibenzenacyclooctaphan-16-ol (1e). Following the general procedure, compound 2 e $(70 \mathrm{mg}, 0.218 \mathrm{mmol})$ was stirred at $0^{\circ} \mathrm{C}$ for $1 \mathrm{~h}$. Silica gel column chromatography $\left(\mathrm{CH}_{2} \mathrm{Cl}_{2} / \mathrm{MeOH}=97: 3\right)$ afforded pure compound $1 \mathrm{e}\left(54 \mathrm{mg}, 80 \%\right.$ yield) as a colorless solid. $\mathrm{Mp}>200^{\circ} \mathrm{C}$. $[\alpha]_{\mathrm{D}}^{20}=+2.5(\mathrm{c}$ $0.4, \mathrm{MeOH}) . \mathrm{IR}$ (neat) $v_{\max }: 3411,1529 \mathrm{~cm}^{-1} .{ }^{1} \mathrm{H}$ NMR $\left(300 \mathrm{MHz}, \mathrm{DMSO}-d_{6}\right) \delta: 7.28$ $(\mathrm{s}, 1 \mathrm{H}) ; 7.10-7.07(\mathrm{~m}, 2 \mathrm{H}) ; 6.79-6.76(\mathrm{~m}, 2 \mathrm{H}) ; 6.72(\mathrm{~d}, J=8.1 \mathrm{~Hz}, 1 \mathrm{H}) ; 6.61$ (dd, $J=$ 8.1, 2.1 Hz, 1H); $4.78(\mathrm{~d}, J=2.1 \mathrm{~Hz}, 1 \mathrm{H})$; 4.25-4.21 (m, 2H); 3.08-3.03 (m, 2H); 3.0$2.93(\mathrm{~m}, 4 \mathrm{H}) \cdot{ }^{13} \mathrm{C}$ NMR (75 MHz, DMSO- $\left.d_{6}\right) \delta: 154.3 ; 149.7 ; 144.7 ; 143.7 ; 137.8$; $131.0 ; 129.8 ; 124.7 ; 122.9 ; 122.3 ; 116.1 ; 115.7 ; 50.8 ; 32.8 ; 32.4 ; 25.8$. HRMS (DCl, $\left.\mathrm{CH}_{4}\right) \mathrm{m} / \mathrm{z}$ calcd for $\mathrm{C}_{18} \mathrm{H}_{18} \mathrm{~N}_{3} \mathrm{O}_{2}[\mathrm{M}+\mathrm{H}]^{+}:$308.1399, found: 302.1402.

\subsection{Biological experiments.}

\subsubsection{Cell culture}

RAW 264.7 murine macrophages were obtained from American Type Culture Collection (Manassas, Virginia), and were cultured in Dulbecco's modified Eagle's medium (DMEM) supplemented with $10 \%$ heat inactivated fetal calf serum in a $37^{\circ} \mathrm{C}$ humidified incubator containing $5 \% \mathrm{CO}_{2}$.

For the experiments, the cells were incubated in serum-free RPMI1640 medium.

\subsubsection{Cell viability assay}

Cell cytotoxicity was evaluated by MTT (3-(4,5-dimethylthizol-2-yl)-2,5diphenyltetrazolium bromide) assay as previous reported [33]. 


\subsubsection{Intracellular ROS determination.}

Intracellular ROS generation was evaluated by measuring the oxidation of $\mathrm{H}_{2}$ DCFDAAM in the previously reported conditions [33]. The probe was added to the culture medium ( $5 \mu \mathrm{M}$ final concentration) $30 \mathrm{~min}$ before the end of the experiment. The cells were washed three times with PBS, and the fluorescence was measured as reported ( $\lambda_{\text {exc }} 495, \lambda_{\text {em }} 520 \mathrm{~nm}$ ). The data are expressed as ratio fluorescence/fluorescence of the LPS-stimulated control.

\subsubsection{Nitrite level assays}

Nitrite production was quantified in the culture medium using the Griess reaction test. Briefly, RAW 264.7 cells were pretreated with the compounds for $30 \mathrm{~min}$, then stimulated with LPS $(20 \mathrm{ng} / \mathrm{mL})$ for $4 \mathrm{~h}$. The isolated supernatants were mixed with an equal volume of Griess reagent. Nitrite production was determined by measuring the absorbance at $550 \mathrm{~nm}$ after 15 minutes of incubation (vs $690 \mathrm{~nm}$ to remove the background) using a microplate reader (Infinite ${ }^{\circledR}$ M200 PRO, Tecan).

\subsubsection{Cytokine mRNA quantification (IL-1 $\beta$ and IL-6)}

Total RNA was isolated from cells with Tri-reagent $R T$ (Euromedex ${ }^{\circledR} \mathrm{RT}-111-50$ ) and retrotranscripted with High-capacity cDNA Reverse Transcription Kit (Applied Biosystems $^{\circledR}$, ref: 4374966). mRNA levels were measured by real-time quantitative polymerase chain reaction with Fast SYBR Green Master Mix kit (Applied Biosystems, ref: 4385612). The following primers were used:

IL-1 $\beta$ : MF 5'-AAGCCTCGTGCTGTCGGACC-3'; $\quad \mathrm{R} \quad$ 5'TCCAGCTGCAGGGTGGGTGT-3', M

IL-6: MF 5'-ATGGATGCACCAAACTGGAT-3'; MR 5'TGAAGGACTCTGGCTTTGTCT

GAPDH: MF 5'-GTATGTCGTGGAGTCTACTG-3', MR 5'TGCTGACAATCTTGAGTGAG-3'

mRNA expression was normalized to GAPDH expression. 


\subsubsection{Statistical Analyses.}

Results are expressed as mean \pm SEM. Statistical analyses were done using Graph Pad Prism 5 for Windows (Graph Pad Software). Parametric tests consisted in Anova test (Dunnet's post hoc). Results were considered significant at $P<0.05$.

\section{Acknowledgments}

The authors acknowledge the financial support from INSERM, CNRS, Universite Paul Sabatier, the French "Ministère de l'Enseignement Supérieur et de la Recherche" 5grant to K.M.), and IdEx Emergence call-PALMA.

The authors wish to thank Nancy Geoffre and the GeT-TQ Platform (INSERM U1048, I2MC), and the Institut de Chimie de Toulouse (FR 3599) for their excellent technical assistance.

\section{Appendix A. Supplementary data}

Supplementary data related to this article can be found at

\section{References and notes}

[1] S. Krishnamoorthy, K.V. Honn, Inflammation and disease progression, Cancer Metastasis Rev. 25 (2006) 481-491. doi:10.1007/s10555-006-9016-0.

[2] R. Curi, R. de Siqueira Mendes, L.A. de Campos Crispin, G. Norata, S. Sampaio, P. Newsholme, A past and present overview of macrophage metabolism and functional outcomes, Clin. Sci. 131 (2017) 1329-1342. doi:10.1042/CS20170220.

[3] E. Culotta, D. Koshland, NO news is good news, Science. 258 (1992) 1862 1865. doi:10.1126/science.1361684.

[4] C. Heiss, A. Rodriguez-Mateos, M. Kelm, Central Role of eNOS in the Maintenance of Endothelial Homeostasis, Antioxid. Redox Signal. 22 (2015) 1230-1242. doi:10.1089/ars.2014.6158.

[5] C.-H. Wu, T.-L. Chen, T.-G. Chen, W.-P. Ho, W.-T. Chiu, R.-M. Chen, Nitric Oxide Modulates Pro- and Anti-inflammatory Cytokines in LipopolysaccharideActivated Macrophages:, J. Trauma Inj. Infect. Crit. Care. 55 (2003) 540-545. doi:10.1097/01.TA.0000033496.62796.3B.

[6] J.T. Mattila, A.C. Thomas, Nitric Oxide Synthase: Non-Canonical Expression Patterns, Front. Immunol. 5 (2014). doi:10.3389/fimmu.2014.00478.

[7] J. MacMicking, Q. Xie, C. Nathan, Nitric Oxide and Macrophage Function, Annu. Rev. Immunol. 15 (1997) 323-350. doi:10.1146/annurev.immunol.15.1.323.

[8] H.H. Schmidt, T.D. Warner, M. Nakane, U. Förstermann, F. Murad, Regulation and subcellular location of nitrogen oxide synthases in RAW264.7 macrophages, Mol. Pharmacol. 41 (1992) 615-624. 
[9] H.A. Lee, E.K. Koh, J.E. Sung, J.E. Kim, S.H. Song, D.S. Kim, H.J. Son, C.Y. Lee, H.S. Lee, C.J. Bae, D.Y. Hwang, Ethyl acetate extract from Asparagus cochinchinensis exerts anti-inflammatory effects in LPS-stimulated RAW264.7 macrophage cells by regulating COX-2/iNOS, inflammatory cytokine expression, MAP kinase pathways, the cell cycle and anti-oxidant activity, Mol. Med. Rep. 15 (2017) 1613-1623. doi:10.3892/mmr.2017.6166.

[10] W. Zhong, K. Qian, J. Xiong, K. Ma, A. Wang, Y. Zou, Curcumin alleviates lipopolysaccharide induced sepsis and liver failure by suppression of oxidative stress-related inflammation via PI3K/AKT and NF-KB related signaling, Biomed. Pharmacother. 83 (2016) 302-313. doi:10.1016/j.biopha.2016.06.036.

[11] Q. Ning, Z. Liu, X. Wang, R. Zhang, J. Zhang, M. Yang, H. Sun, F. Han, W. Zhao, X. Zhang, Neurodegenerative changes and neuroapoptosis induced by systemic lipopolysaccharide administration are reversed by dexmedetomidine treatment in mice, Neurol. Res. 39 (2017) 357-366.

doi:10.1080/01616412.2017.1281197.

[12] C.H. Park, M.-R. Shin, B.K. An, H.W. Joh, J.C. Lee, S.-S. Roh, T. Yokozawa, Heat-Processed Scutellariae Radix Protects Hepatic Inflammation Through the Amelioration of Oxidative Stress in Lipopolysaccharide-Induced Mice, Am. J. Chin. Med. (2017) 1-20. doi:10.1142/S0192415X17500689.

[13] J.H. Tabares-Guevara, O.J. Lara-Guzmán, J.A. Londoño-Londoño, J.A. Sierra, Y.M. León-Varela, R.M. Álvarez-Quintero, E.J. Osorio, J.R. Ramirez-Pineda, Natural Biflavonoids Modulate Macrophage-Oxidized LDL Interaction In Vitro and Promote Atheroprotection In Vivo, Front. Immunol. 8 (2017). doi:10.3389/fimmu.2017.00923.

[14] S.K. Biswas, Does the Interdependence between Oxidative Stress and Inflammation Explain the Antioxidant Paradox?, Oxid. Med. Cell. Longev. 2016 (2016) 1-9. doi:10.1155/2016/5698931.

[15] S. Sarkar, S. Mazumder, S. J. Saha, U. Bandyopadhyay, Management of Inflammation by Natural Polyphenols: A Comprehensive Mechanistic Update, Curr. Med. Chem. 23 (2016) 1657-1695. doi:10.2174/0929867323666160418115540.

[16] S. Kumar, A.K. Pandey, Chemistry and Biological Activities of Flavonoids: An Overview, Sci. World J. 2013 (2013) 1-16. doi:10.1155/2013/162750.

[17] T. Hussain, B. Tan, Y. Yin, F. Blachier, M.C.B. Tossou, N. Rahu, Oxidative Stress and Inflammation: What Polyphenols Can Do for Us?, Oxid. Med. Cell. Longev. 2016 (2016) 1-9. doi:10.1155/2016/7432797.

[18] W.F. McCalmont, J.R. Patterson, M.A. Lindenmuth, T.N. Heady, D.M. Haverstick, L.S. Gray, T.L. Macdonald, Investigation into the structure?activity relationship of novel concentration dependent, dual action T-type calcium channel agonists/antagonists, Bioorg. Med. Chem. 13 (2005) 3821-3839. doi:10.1016/j.bmc.2005.03.004.

[19] B.R. Rajaganapathy, Molecular basis of the anti-inflammatory potential of a diarylheptanoid in murine macrophage RAW 264.7 cells, Adv. Biol. Chem. 3 (2013) 541-548.

[20] K. Maurent, C. Vanucci-Bacqué, N. Saffon-Merceron, M. Baltas, F. BedosBelval, Total Synthesis of Tedarene A, J. Nat. Prod. 80 (2017) 1623-1630. doi:10.1021/acs.jnatprod.7b00199.

[21] V. Costantino, E. Fattorusso, A. Mangoni, C. Perinu, R. Teta, E. Panza, A. lanaro, Tedarenes A and B: Structural and Stereochemical Analysis of Two New 
Strained Cyclic Diarylheptanoids from the Marine Sponge Tedania ignis, J. Org. Chem. 77 (2012) 6377-6383. doi:10.1021/jo300295j.

[22] C.A.G.N. Montalbetti, V. Falque, Amide bond formation and peptide coupling, Tetrahedron. 61 (2005) 10827-10852. doi:10.1016/j.tet.2005.08.031.

[23] Recent Developments in Hydantoin Chemistry. a Review - Org Prep Proced Int, 2004, 36(5), 391 - 00304940409356627 - Carfentanil | Amine | Ester, Scribd. (n.d.). https://fr.scribd.com/document/118352718/Recent-Developments-inHydantoin-Chemistry-a-Review-Org-Prep-Proced-Int-2004-36-5-39100304940409356627-Carfentanil (accessed October 3, 2017).

[24] D. Dheer, V. Singh, R. Shankar, Medicinal attributes of 1,2,3-triazoles: Current developments, Bioorganic Chem. 71 (2017) 30-54. doi:10.1016/j.bioorg.2017.01.010.

[25] F. Yokokawa, A. Inaizumi, T. Shioiri, Synthetic studies of the cyclic depsipeptides bearing the 3-amino-6-hydroxy-2-piperidone (Ahp) unit. Total synthesis of the proposed structure of micropeptin T-20, Tetrahedron. 61 (2005) 1459-1480. doi:10.1016/j.tet.2004.12.009.

[26] C. Sambiagio, S.P. Marsden, A.J. Blacker, P.C. McGowan, Copper catalysed Ullmann type chemistry: from mechanistic aspects to modern development, Chem Soc Rev. 43 (2014) 3525-3550. doi:10.1039/C3CS60289C.

[27] L. Shen, C.J. Simmons, D. Sun, Microwave-assisted synthesis of macrocycles via intramolecular and/or bimolecular Ullmann coupling, Tetrahedron Lett. 53 (2012) 4173-4178. doi:10.1016/j.tetlet.2012.05.142.

[28] H. Liu, Z. Yang, Z. Pan, Synthesis of Highly Substituted Imidazolidine-2,4-dione (Hydantoin) through Tf 2 O-Mediated Dual Activation of Boc-Protected Dipeptidyl Compounds, Org. Lett. 16 (2014) 5902-5905. doi:10.1021/ol502900j.

[29] D.L. Boger, D. Yohannes, Intramolecular Ullmann condensation reaction: an effective approach to macrocyclic diaryl ethers, J. Org. Chem. 56 (1991) 17631767. doi:10.1021/jo00005a020.

[30] S.I. Sviridov, A.A. Vasil'ev, N.L. Sergovskaya, M.V. Chirskaya, S.V. Shorshnev, Azidosubstituted arylboronic acids: synthesis and Suzuki-Miyaura crosscoupling reactions, Tetrahedron. 62 (2006) 2639-2647. doi:10.1016/j.tet.2005.12.026.

[31] J. Keilitz, S.G. Newman, M. Lautens, Enantioselective Rh-Catalyzed Domino Transformations of Alkynylcyclohexadienones with Organoboron Reagents, Org. Lett. 15 (2013) 1148-1151. doi:10.1021/ol400363f.

[32] R.-M. Chen, T.-G. Chen, T.-L. Chen, L.-L. Lin, C.-C. Chang, H.-C. Chang, C.-H. Wu, Anti-Inflammatory and Antioxidative Effects of Propofol on Lipopolysaccharide-Activated Macrophages, Ann. N. Y. Acad. Sci. 1042 (2005) 262-271. doi:10.1196/annals.1338.030.

[33] B. Bouguerne, N. Belkheiri, F. Bedos-Belval, C. Vindis, K. Uchida, H. Duran, M.H. Grazide, M. Baltas, R. Salvayre, A. Nègre-Salvayre, Antiatherogenic effect of bisvanillyl-hydralazone, a new hydralazine derivative with antioxidant, carbonyl scavenger, and antiapoptotic properties, Antioxid. Redox Signal. 14 (2011) 2093-2106. doi:10.1089/ars.2010.3321.

[34] L. Das, M. Vinayak, Curcumin attenuates carcinogenesis by down regulating proinflammatory cytokine interleukin-1 (IL-1 $\alpha$ and IL-1 $1 \beta$ ) via modulation of AP-1 and NF-IL6 in lymphoma bearing mice, Int. Immunopharmacol. 20 (2014) 141147. doi:10.1016/j.intimp.2014.02.024.

[35] Z. Gong, J. Zhou, H. Li, Y. Gao, C. Xu, S. Zhao, Y. Chen, W. Cai, J. Wu, Curcumin suppresses NLRP3 inflammasome activation and protects against 
LPS-induced septic shock, Mol. Nutr. Food Res. 59 (2015) 2132-2142. doi:10.1002/mnfr.201500316. 